\title{
A Prelimin ary Analysis of the Postulated Changes Needed to Achieve Rail Cask Handling Capabilities at Selected Light Water Reactors
}

\section{G. J. Konzek}

February 1986

Prepared for the U.S. Department of Energy under Contract DE-AC06-76RLO 1830

Pacific Northwest Laboratory

Operated for the U.S. Department of Energy by Battelle Memorial Institute 


\title{
DISCLAIMER
}

This report was prepared as an account of work sponsored by an agency of the United States Government. Neither the United States Government nor any agency thereof, nor any of their employees, makes any warranty, express or implied, or assumes any legal liability or responsibility for the accuracy, completeness, or usefulness of any information, apparatus, product, or process disclosed, or represents that its use would not infringe privately owned rights. Reference herein to any specific commercial product, process, or service by trade name, trademark, manufacturer, or otherwise, does not necessarily constitute or imply its endorsement, recommendation, or favoring by the United States Government or any agency thereof. The views and opinions of authors expressed herein do not necessarily state or reflect those of the United States Government or any agency thereof.

\author{
PACIFIC NORTHWEST LABORATORY \\ operated by \\ BATTELLE \\ for the \\ UNITED STATES DEPARTMENT OF ENERGY \\ under Contract DE-AC06-76RLO 1830
}

\begin{tabular}{|c|c|}
\hline \multirow{2}{*}{\multicolumn{2}{|c|}{ Printed in the United States of America }} \\
\hline & \\
\hline \multirow{2}{*}{\multicolumn{2}{|c|}{$\begin{array}{l}\text { National Technical Information Service } \\
\text { United States Department of Commerce }\end{array}$}} \\
\hline & \\
\hline \multicolumn{2}{|c|}{5285 Port Royal Road } \\
\hline \multicolumn{2}{|c|}{ Springfield, Virginia 22161} \\
\hline \multirow{2}{*}{\multicolumn{2}{|c|}{$\begin{array}{l}\text { NTIS Price Codes } \\
\text { Microfiche } A 01\end{array}$}} \\
\hline & \\
\hline \multicolumn{2}{|c|}{ Printed Copy } \\
\hline & Price \\
\hline Pages & Codes \\
\hline $001-025$ & $\mathrm{~A} 02$ \\
\hline $026-050$ & $\mathrm{~A} 03$ \\
\hline 051-075 & $\mathrm{A} 04$ \\
\hline $076-100$ & A05 \\
\hline $101-125$ & A06 \\
\hline $126-150$ & A07 \\
\hline $151-175$ & A08 \\
\hline $176-200$ & $\mathrm{~A} 09$ \\
\hline $201-225$ & A010 \\
\hline 226-250 & A011 \\
\hline $251 \cdot 275$ & $\wedge 012$ \\
\hline $276-300$ & A013 \\
\hline
\end{tabular}




\section{A PREL IMINARY ANALYSIS OF THE POSTULATED CHANGES NEEDED TO ACHIEVE RAIL CASK \\ HANDLING CAPABILITIES AT SELECTED LIGHT WATER REACTORS}

G. J. Konzek

February 1986

Prepared for the U.S. Department of Energy under Contract DE-ACO6-76RLO 1830

Pacific Northwest Laboratory Richland, Washington 99352 


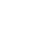

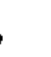

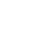

, 


\section{ABSTRACT}

This report presents the results of an assessment sponsored by the U.S. Department of Energy (DOE) through its Monitored Retrievable Storage (MRS) Program at the Pacific Northwest Laboratory. The assessment was made to determine which light water reactors (LWRs) could achieve spent fuel rail shipping cask handling capabilities (and at what approximate costs) where such capabilities currently do not exist. The results are intended to provide data for assessing potential transportation system improvements that could lead to benefits similar to those that would exist if an MRS facility is included in the federal waste management system. Use of an MRS facility will reduce total shipment miles for radioactive wastes in the waste management system. Reducing shipment miles would, in turn, reduce the overall impact of the transportation function and simplify its control. Increasing the fraction of shipments using rail casks would also lead to reductions in shipment miles in either an iMS or a no-MRS waste management system.

Reactor-specific railroad and crane information for all LWRS in the U.S. was extracted from current sources of information. Based on this information, reactors were separated into two basic groups consisting of reactors with existing, usable rail cask capabilities and those without these capabilities. The latter group is the main focus of this study. The group of reactors without present rail cask handling capabilities was further separated into two subgroups consisting of reactors considered essentially incapable of handling a large rail cask of about 100 tons and reactors where postulated facility changes could result in rail cask handling capabilities.

Based on a selected population of 127 reactors, the results of this assessment indicate that usable rail cask capabilities exist at $83(65 \%)$ of the reactors. Twelve $(27 \%)$ of the remaining 44 reactors are deemed incapable of handling a large rail cask without major changes, and 32 reactors are considered likely candidates for potentially achieving rail cask handling capabilities. In the latter group, facility changes were postulated that would conceptually enable these reactors to handle large rail casks. Preliminary estimates of costs to achieve these capabilities were then developed. 
The estimated cost per plant of required facility changes varied widely from a high of about $\$ 35$ million to a low of less than $\$ 0.3$ million. Only 11 of the 32 plants would require crane upgrades. Spur track and right-of-way costs would apparently vary widely among sites. These results are based on preliminary analyses using available generic cost data. They represent lower bound values that are useful for developing an initial assessment of the viability of the postulated changes on a system-wide basis, but are not intended to be absolute values for specific reactors or sites. More information from additional studies would be required to reduce uncertainties in the cost estimates. 


\section{ACKNOWLEDGMENTS}

This document was published under the U.S. Department of Energy's Monitored Retrievable Storage (MRS) Program. The contributions from the following individuals are gratefully acknowledged. The author wishes to thank M. R. Shay of the Pacific Northwest Laboratory for providing overall project guidance and a thorough review of the draft version of this report. Special thanks also go to P. M. Daling, J. F. Fletcher, G. W. McNair, and M. B. Triplett of the Pacific Northwest Laboratory for providing valuable contributions to this report. The editorial review prior to publication was contributed by C. A. Counts. 


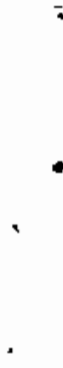


CONTENTS

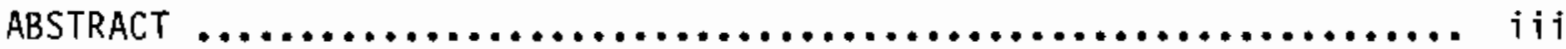

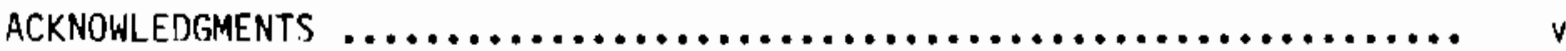

1.0 INTRODUCTION $\ldots \ldots \ldots \ldots \ldots \ldots \ldots \ldots \ldots \ldots \ldots \ldots \ldots \ldots \ldots \ldots \ldots, 1.1$

2.0 SUMMARY AND CONCLUSIONS $\ldots \ldots \ldots \ldots \ldots \ldots \ldots \ldots \ldots \ldots \ldots \ldots \ldots, 2.1$

2.1 RESULTS OF THE DATA REVIEW OF SPENT FUEL RAIL SHIPPING CASK CAPABILITIES $\ldots \ldots \ldots \ldots \ldots \ldots \ldots \ldots \ldots \ldots \ldots, 2.2$

2.2 PRELIMINARY ESTIMATES OF THE COSTS OF CHANGES FOR THE SELECTED REACTORS OF INTEREST $\ldots \ldots \ldots \ldots \ldots \ldots \ldots \ldots, 2.3$

3.0 OBJECTIVE, APPROACH, AND STUDY ASSUMPTIONS $\ldots \ldots \ldots \ldots \ldots \ldots \ldots . . .1$

3.1 STUDY OBJECTIVF. $\ldots \ldots \ldots \ldots \ldots \ldots \ldots \ldots \ldots \ldots \ldots \ldots \ldots \ldots, 3.1$

3.2 TECHNICAL APPROACH $\ldots \ldots \ldots \ldots \ldots \ldots \ldots \ldots \ldots \ldots \ldots \ldots, 3.1$

3.3 STUDY ASSUMPTIONS $\ldots \ldots \ldots \ldots \ldots \ldots \ldots \ldots \ldots \ldots \ldots \ldots \ldots, \quad 3.5$

4.0 SPENT FUEL RAIL SHIPPING CASK FEASIBILITY ASSESSMENTS

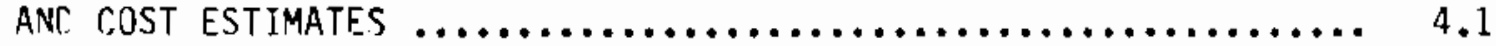

4.1 RESIJLTS OF THE NATA REVIEW OF SPENT FUEL RAIL SHIPPING CASK CAPABILITIES $\ldots \ldots \ldots \ldots \ldots \ldots \ldots \ldots \ldots \ldots \ldots, 4.1$

4.2 REACTORS NOT SUBJECTED TO FURTHER CONSIDERATION

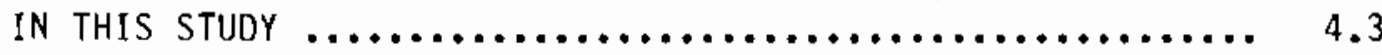

4.3 PRELIMINARY ESTIMATES FDR THE COSTS OF CHANGES AT THE SELECTED REACTORS DF INTEREST $\ldots \ldots \ldots \ldots \ldots \ldots \ldots \ldots, 4.3$

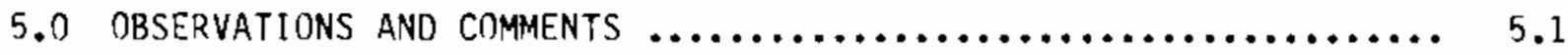

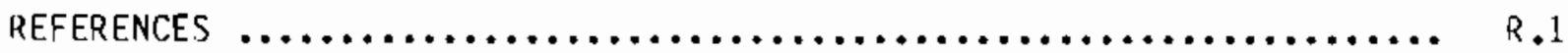

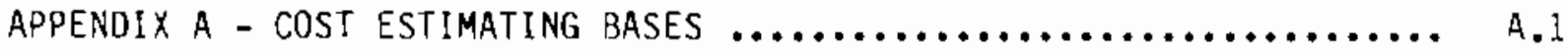

APPENDIX B - PRELIMINARY COST ESTIMATES FOR 32 SELECTED LWRS ....... B. 1 


\section{FIGURES}

3.1 Rail Cask Study Methodology $\ldots \ldots \ldots \ldots \ldots \ldots \ldots \ldots \ldots \ldots \ldots \ldots \ldots \ldots . \ldots . \ldots . \ldots$

\section{TABLES}

2.1 Estimated Costs of Changes to Achieve Rail Cask Capability at the Selected LWRs Utilized in this Study $\ldots \ldots \ldots \ldots \ldots \ldots \ldots . . . \ldots 2.4$

3.1 Current Spent Fuel Rail Shipping Cask Capabilities of

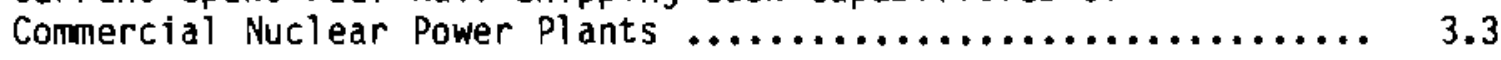

4.1 Rail Cask Capability as a Function of the Number of Reactors on a Site $\ldots \ldots \ldots \ldots \ldots \ldots \ldots \ldots \ldots \ldots \ldots \ldots \ldots \ldots \ldots . \ldots \ldots . \ldots \ldots$

4.2 Reactors Not Further Evaluated in this Study .............. 4.4

4.3 Selected LWRs Utilized in this Study $\ldots \ldots \ldots \ldots \ldots \ldots \ldots \ldots \ldots \ldots$

4.4 Estimated Costs of Changes to Achieve Rail Cask Capability at the Selected LWRs Utilized in this Study ............... 4.6 


\subsection{INTRODIUCTION}

Identifying which light water reactors (LWRs) in the U.S. could achieve spent fuel rail shipping cask capabilities (and at what approximate costs) where no such capabilities currently exist is both important and timely. Some tisilibiss are in various stages of assessing and/or implementing plans designed to expand their spent fuel storage capacities. These plans may include 1) physical changes associated with the spent fuel storage pool itself, 2) studies of spent fuel rod consolidation, or 3) preparations for participation in government-sponsored fuel rod consolidation or dry cask storage demonstration programs. Therefore, it should he recognized that currently there is very little notivition or incentive for licensees to spend money for alteration or conversion of existing cranes or to build spur tracks. However, as the U.S. Department of Energy (DOE) begins accepting spent fuel from reactors for eventual disposal in geologic repositories, utilities may find it advantageous to use rail casks, if possible, to reduce the impact of shipping campaigns on reactor operations. The resutts of this assessment are intended to provide data for use in assessing one set of potential transportation system improvements that could lead to benefits similar to those that would exist if an MRS facility was included in the federal waste management system. The MRS facility would reduce tota? shipment miles in the system which would reduce the overall impact of the transportation function and simplify its control. Increasing the fraction of spent flel shipments using rail casks would also lead to renuctions in shipment miles in either an MRS or no-MRS waste management system.

Section 2 of this report presents the summary and conclusions of this assessment. The study approach taken for the assessment is presented in Section 3. The details of the rail shipping cask feasihility assessment and preliminary cost estimates for the selected reactors of interest are presented in Section 4. A discussion of observations and comments based on this feasibility assessment is presented in Section 5 .

The hases used to develop cost estimates for the postulated facility changes which potentially result in rail cask handling capabilities are described in Appendix A. Other cost factors that are difficult to quantify 
generically are also included in Appendix A for completeness. Preliminary estimates of the costs to achieve spent fuel rail cask capabilities at the reactors examined in this study are presented in Appendix $B$. 


\subsection{SUMMARY AND CONCLUSIONS}

The results of this study, which was sponsored by the U.S. Department of Energy (DOE) through its Monitored Retrievable Storage (MRS) program at Pacific Northwest Laboratory, are summarized in this section. The purpose of the study is to determine which light water reactors (LWRs) could achieve spent fuel rail cask capabilities (and at what approximate costs) where such capabilities do not currently exist. The estimates derived in this study will provide data for use in the MRS program. This pretiminary analysis was accomplished by examining current sources of information to extract reactor-specific railroad and crane information for all LWRS in the U.S. Based upon this information, reactors were separated into two basic groups consisting of those reactors with existing, usable rail cask capabilities and those without these capabilities. The latter group is the main focus of this study. This group of reactors was further separated into two subgroups consisting of reactors considered essentially incapable of handling a large rail cask of about 100 tons (due to crane and/or structural limitations) and reactors where other changes (e.g., addition of a rail spur or minor crane upgrades) could result in rail cask handling capabilities.

Reactor-specific modifications that would conceptually result in rail cask handling capabilities at 32 selected LWRs were developed. After identifying the parameters of interest associated with the postulated changes, preliminary estimates of the costs to achieve these capabilities were then developed.

Since spur track and right-of-way costs vary in relation to the distance from the reactor sites to railroad mainlines and only 11 of the 32 plants reeded crane ipgrades, the cost per plant of required upgrades varied widely from a high of about $\$ 35$ million to a low of less than $\$ 0.3$ million. These results are based on preliminary analyses using available generic cost data. The results represent lower bound values that are useful for developing an initial assessment of the viability of the postulated changes on a system-wide basis, but are not intended to be absolute values for specific reactors. Additional in-depth studies would be required to obtain reactor-specific estimates. In-depth information on a variety of conditions not addressed in this 
study would be required for each reactor site before such reactor-specific cost estimates could be obtained. Information to support these cost estimates might include:

- the effect of additions of equipment and/or piping since commercial operation began; corollary areas which might be affected include updating as-built drawings to determine existing crane clearances and other cask-loading bay/building changes that could be required to accommodate the various size rail casks (e.g., enlargement of a hatch or building entrance)

- structural analysis, testing, and reporting requirements associated with upgrading a reactor's cask handling crane, including the determination of needs and costs concerning specific contracts, schedules, miscellaneous licensing-related activities, permitting (if required), and other regulatory reviews and requirements

- the cost of railroad bridges where needed.

2.1 RESULTS OF THE DATA REVIEW OF SPENT FIJEL RAIL SHIPPING CASK CAPABILITIES

The results of this assessment indicate that usable rail cask capabilities exist at $83(65 \%)$ of the 127 reactors considered. Twelve (27\%) of the remaining 44 reactors were felt to be incapable of handling a large rail cask, and 32 reactors could potentially achieve rail cask handling capabilities.

Twelve nuclear power plants were not subjected to further evaluation in this study primarily because of their limited crane capacities (see Section 4.2 for detaits).

The 32 reactors chosen for further examination are briefly discussed in the following section, together with a summary of the costs associated with the postulated changes that would conceptually enable rajl cask handing capabilities to be achieved at these plants by 1995. For this study, it is assumed that the MRS facility will begin receiving spent fuel in the 1996-98 time frame. 


\subsection{PRELIMINARY ESTIMATES OF THE COSTS OF CHANGES FOR THE SELECTED REACTORS OF INTEREST}

The estimated costs of postulated changes to achieve rail cask capabilities at the 32 selected LWRs are summarized in Table 2.1. It can be seen from the table that crane alterations are assumed to be required at 11 reactors. The primary reason for these alterations is to upgrade the cranes' capacities to safely handle a future cask design which will probably weigh about 100 tons when fully loaded. In all cases, it was assumed that crane alterations could be accomplished by replacing the trolley. This change is expected to incur a nominal cost of about $\$ 1$ million per unit.

It was estimated that expenditures in the following ranges would be neces sary to achieve rail cask handling capabilities at various reactors: $\$ 0.2 \mathrm{mil-}$ lion to $\$ 5$ million at 16 reactors, $\$ 5$ million to $\$ 10$ million at six reactors, and greater than $\$ 10$ million per plant at the remaining six reactors. Four reactors shown in Table 2.1 are connected to their sister units either by a transfer canal or by sharing a common spent fuel storage pool. In these cases, it was assumed that the cost of changes at the first unit was the total cost involved for both units. In general, the major contributor to the total cost for changes at individual plants within each of these groups is the length of the spur track that would need to be constructed. Because of the length of the spur track needed, the Calvert Cliffs site was estimated at $\$ 35$ million to be the most costly modification project.

The reader is cautioned that the cost estimates developed in this study are preliminary in nature and subject to change upon receipt of additional site-specific details. Additional in-depth study is recommended because complex issues are invoived for each plant. It is estimated that successful implementation of the postulated reactor-specific changes presented in this study, on a reasonable schedule, could provide rail cask handling capabilities at the selected reactors in the 1995 time frame. However, the preliminary results presented in this study are not intended to be used to require a particular mode of shipping from any reactor. 
TABLE 2.1. Estimated Costs of Changes to Achieve Rail Cask Capability at the Selected LWRs Utilized in this Study (a)

\begin{tabular}{|c|c|c|c|c|}
\hline \multirow[b]{2}{*}{ Plant (Type) } & \multicolumn{3}{|c|}{ Postulated Changes } & \multirow{2}{*}{$\begin{array}{c}\text { Estimated } \\
\text { Cost, Millions, }) \\
(1984 \text { dollars })(b, c)\end{array}$} \\
\hline & Crane & $\begin{array}{l}\text { Spur Trad } \\
\text { Onsite }\end{array}$ & $\begin{array}{l}\text { miles } \\
\text { Offsite }\end{array}$ & \\
\hline Browns Ferry-1 (BWR) & Alter trolley & 1 & 6 & 7.14 \\
\hline Browns Ferry-2 (BWR) & (d) & $\cdots$ & -- & 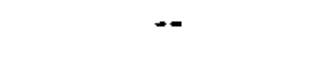 \\
\hline Browns Ferry-3 (BHR) & A1ter trolley & 1 & -- & 1.80 \\
\hline Callaway-1 (PWR) & -- & 1 & -- & 0.41 \\
\hline Calvert Cliffs-l (PWR) & -- & 1 & 39 & 35.35 \\
\hline Calvert $\mathrm{Cl}$ iffs-2 (PWR) & (d) & -- & -- & -- \\
\hline Connecticut Yankee (PWR) & Alter trolley & 1 & 9 & 9.75 \\
\hline Crystal River-3 (PWR) & -- & 1 & -- & 0.41 \\
\hline Diablo Canyon-1 (PWR) & -- & 1 & 19 & 17.05 \\
\hline Niablo Canyon-2 (PWR) & $\rightarrow$ & 1 & 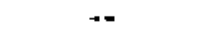 & 0.41 \\
\hline Hope Creek (BWR) $(e)$ & -- & 1 & -- & 0.41 \\
\hline Kewaunee (PWR) & $\because$ & 1 & 4 & 4.01 \\
\hline Oconee-I (PWR) & Alter trolley & 1 & 9 & 9.75 \\
\hline Oconee-2 (PWR) & (f) & -- & -- & -- \\
\hline Dconee- 3 (PWR) & Alter trolley & 1 & -- & 1.80 \\
\hline Oyster Creek (BWR) & Alter trolley & 1 & 14 & 14.10 \\
\hline Palisades (PHR) $(g)$ & Alter trolley & 1 & -- & 1.80 \\
\hline Peach Bottom-2 (BWR) & $\cdots$ & 1 (гераir) & 19 (repair) & 16.71 \\
\hline Peach Bottom-3 (BWR) & $\cdots$ & 1 (repair) & -- & 0.41 \\
\hline Pilgrim-1 (BWR) & Alter trolley & 1 & 9 & 9.75 \\
\hline Saiem-1 $(P W R)^{(e)}$ & $\cdots$ & 1 & 14 & 12.71 \\
\hline Salem-2 (PWR) $(\mathrm{e})$ & -- & 1 & $\cdots$ & 0.41 \\
\hline San 0nofre-1 (PWR) & Alter trolley & $<1$ & $\cdots$ & 1.80 \\
\hline San Onofre-2 (PWR) & -- & $<1$ & $\because$ & 0.41 \\
\hline San Onofre-3 (PWR) & -- & $<1$ & -- & 0.41 \\
\hline Shoreham (BWR) $(g)$ & - & 1 & 9 & 8.36 \\
\hline Surry-1 (PHR) & -- & 1 & 25 & 22.29 \\
\hline Surry-? $(P W R)$ & $(f)$ & -- & $\rightarrow$ & -- \\
\hline Trojan (DWR) & $\rightarrow$ & $<1$ & -- & 0.41 \\
\hline Turkey $P_{0 i n t-3}(P \mathrm{NR})$ & Alter trolley & 1 & 9 & 9.75 \\
\hline Turkey Point-4 (PwR) & Alter trolley & $<1$ & $\rightarrow$ & 1.80 \\
\hline WNP-? $(B N R)$ & -- & $<1 \quad($ repair) & -- & 0.21 \\
\hline
\end{tabular}

(a) Cranes rated at approximately 100 tons (see Table 3.1 for details) are assumed to be upgraded to about 125 tons to safely handle the future cask design weighing about 100 tons as tiscussed in Section 3.1 .

(b) The number of figures shown is for conputational accuracy and does not imply precision to that many significant figures. Tetails of reactor-specific cost estimates are contained in Appendix 3.

(c) Includes $25 \%$ cont ingency.

(d) No crane modifications required; pool connected by transfer canal to Innit 1 .

(e) Hope Creek, Salem 1 , and Salem ? are on the same site.

(f) No crane modifications required; common pool shared with unit 1.

(g) Additional information is needed to confirm that the dimensions of the cask loading pool can accommodate $\rightarrow$ large rafl cask. 


\subsection{ORJECTIVE, APPROACH, AND STIJPY ASSIMMPTIONS}

This section contains brief descriptions of the objective, technical approach, and assumptions utilized in this study.

\subsection{STIIDY OBJECTIVE}

The objective of this study is to determine which light water reactors (LWRs) could achieve spent fuel rail shipping cask capabilities (and at what approximate costs) where none currently exists. To accomplish this objective, the baseline information reported by Daling et al. (1985) as well as other sources of information available in the open literature were used. Preliminary feasibility assessments were performed to determine the existing and the potential capabilities of all LWRs to ship spent fuel by rail. Selected parameters were identified and used to estimate each plant's capability to safely handle a future cask design that will probably weigh about 100 tons when fully loaded.

This assessment is intended to provide data for use in assessing potential transportation system improvements that could lead to benefits similar to those that would exist if an MRS facility was included in the federal waste management system.

\subsection{TECHNICAL APPROACH}

A methodology was developed to assist in the process of selecting the reactors examined in this study. The study methodology is illustrated in Figure 3.1. The first step in the process was to acquire background information from the open literature and from nuclear plant and industry personnel familiar with the suhject areas of interest.

The raw data presented hy Daling et al. (1985) was examined to extract railroad and crane information for all LWRs in the Inited States. In addition, other sources of information in the open Titerature (e.g., FSARs) were used for the same purpose. The results of this effort are presented in Table 3.1. 


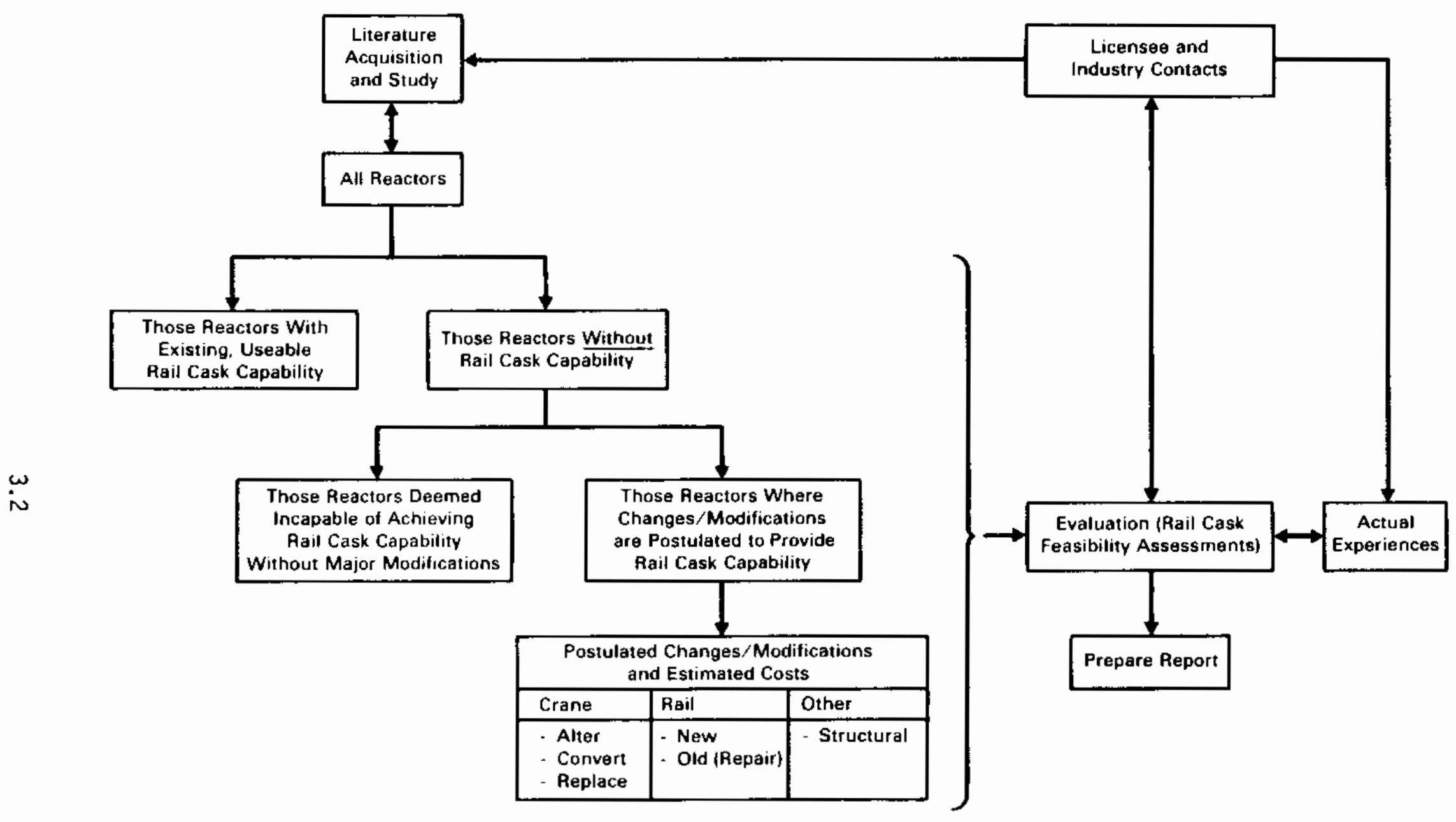

FIGURE 3.1. Rail Cask Study Methodology 
TABLE 3.1. Current Spent Fuel Rail Shipping Cask Capabilities of Commercial Nuclear Power Plants

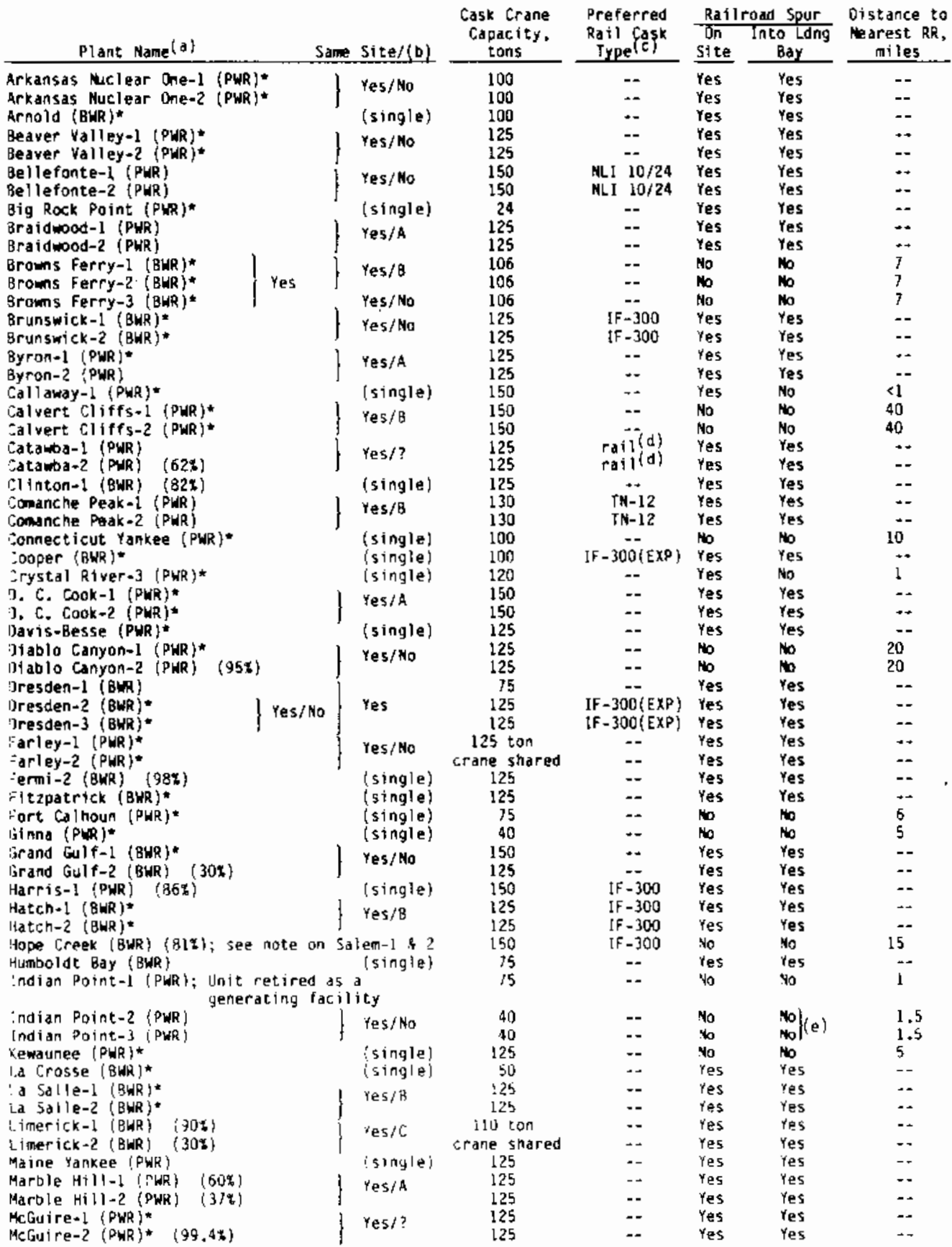

la) Asterisk (*) denotes operating plants; PWR 15 pressurized water reactor and ghR is hoiling water reactor: and (b) indicates approximate percent complete.

b) A indicates common pool shared by two reactors.

$B$ indicates poots connected by transfer cand.

C indicates pools connected by cask transfer.

"No". indicates no sharing capabilities: plant has its om crane and pool.

(c) (EXP\} means experience with that type of cask; and,".." means preferred rail cask not specified.

(d) Vo specific preferred rail cask type was indicated by the licensee.

(e) An internal utility study shawed the cost of adding rail would be excessive due to severe terrain (NAC 1977). 
TABLE 3.1. (contd)

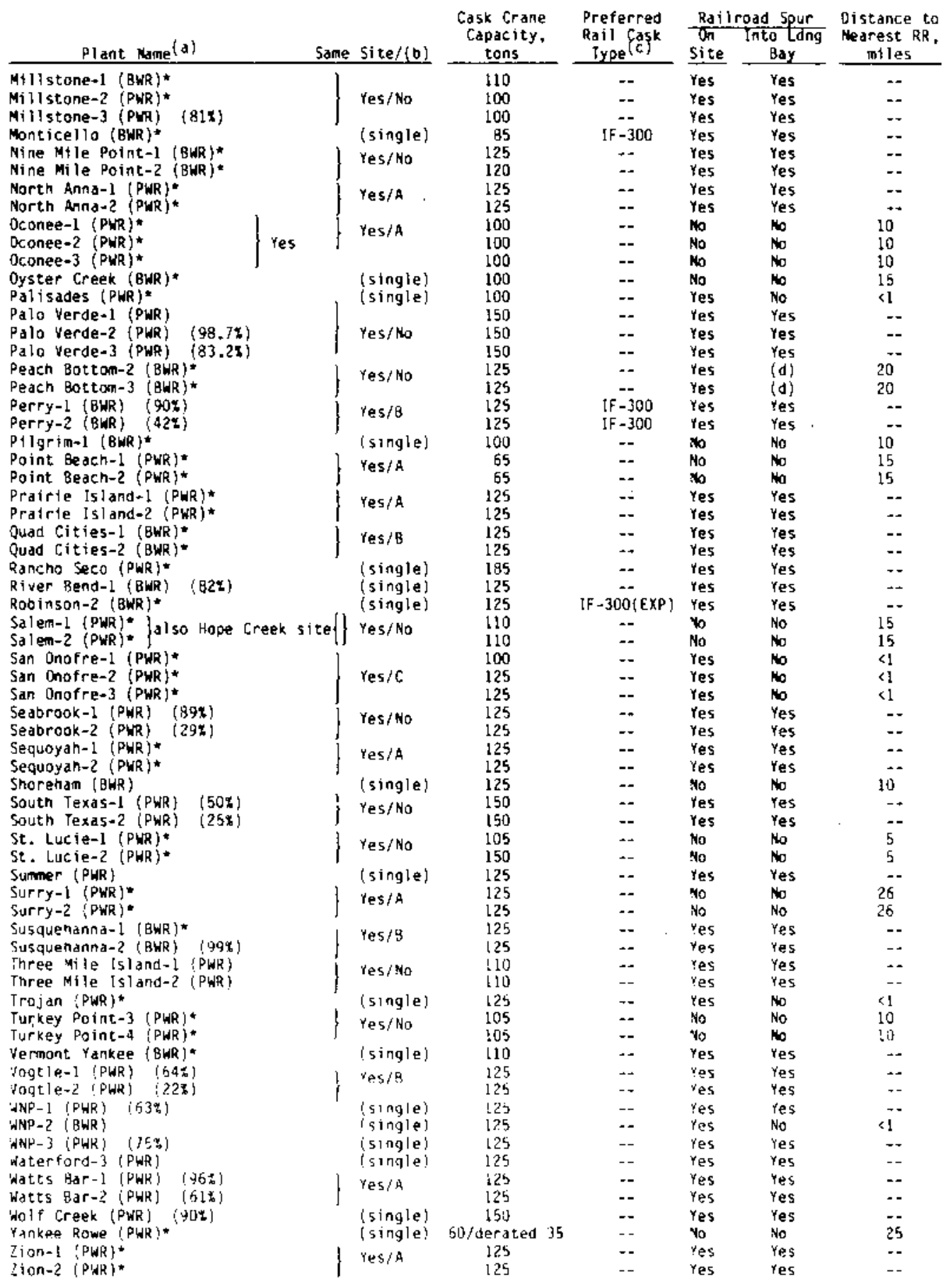

(a) Asterisk $1^{*}$ ) denotes uperating $p /$ ants; jnd : indicates dpproximate percent ;onplete.

(b) A indicates comon pool shared by two reactors.

B indicates pools connected by transfer canal.

C incicates pools connected by cask transfer.

"No" indicates no sharing capabilities; plant has its awn crane and pool.

(c) (EXP) means experience with that kype of cask: and, "-." weans preferred rall cask not specified.

(d) Licensee states a railroad is ansite but unsuitable for use. 
Based upon the information in Table 3.1, the reactors were separated into two basic groups: 1) those reactors with existing, usable rail cask capabilities and 2) those without this capability. The latter group is the main focus of this study. Based upon engineering judgment, these reactors were further separated into two sub-groups: 1) those reactors where postulated changes coutd provide rail cask capability, and 2) those reactors determined to be essentially incapable of achieving a rail cask handling capability. Study results and additional information of interest are presented in Section 4.0 .

\subsection{STINYY ASSIMMPTIDNS}

Numerous specific assumptions were made to facilitate the analyses which are described in this report. The following general assumptions were used:

1. All postulated changes could he accomplished without interrupting operations. Otherwise, the potential for significant costs for downtime must be considered.

2. Typical unit cost is utilized in Appendix B for rail track cost per mile. In reality such costs would be hased on terrain (e.g., whether level ground or hilly country must be traversed by the tracks) as well as other factors not within the scope of this preliminary study (e.g., whether a railroad bridge is required).

3. The unit costs for new railroad track and for old railroad track in need of repair are considered to be the same.

4. Various reference sources list sightly different distances from the site (cask loading hay) to a railroad mainline; therefore, for purposes of this analysis, the most recent information compiled by Daling et al. (1985) is used.

5. Cranes rated at approximately 100 tons (see Table 3.1 for details) are assumed to be upgraded to about 125 tons capacity to safely handle the future cask design (weighing about 100 tons) discussed previously in Section 3.1. Preliminary cost estimates for 11 crane upgrades are given in Appendix B. Because the upgrading involves only trolley replacement to provide for nominal increased lifting 
capacity at the selected plants, no associated building structural modifications are assumed to be necessary. However, since this must be proven to the U.S. Nuclear Regulatory Commission (NRC), estimated costs for technical evaluations associated with the crane modifications are provided in Appendix A for completeness.

6. At some reactors, cask loading pool use may be restricted to certain cask designs because of loading pool dimensional constraints. This will have to be detemined on a case-hy case basis.

7. With the exception of Marble Hill lnits 1 and 2, which have been canceled, all the reactors currently under construction as shown in Table 3.1 are assumed to he in operation in the 1995 time frame of interest to this study. 


\section{I SPENT FUEL RAIL SHIPPING CASK FEASIBILITY ASSESSMENTS AND COST ESTIMATES}

This section presents the results of the assessment to determine which light water reactors (LWRs) could potentially achieve spent fuel rail shipping cask capabilities (and at what approximate costs) where such capability does not currently exist. Based upon the identified cask handling limitations, evaluations were performed which used engineering judgment as well as selected quantified elements. Some factors (e.g., crane capacity, railroad onsite characteristics, etc.) were quantifiable, thus narrowing the remaining area where engineering judgment had to be used. Assumptions were used where necessary in the development of reactor-specific modifications to cask handling facilities that would conceptually result in rail cask handling capabilities at the selected reactors. After identifying the parameters of interest associated with the postulated changes, preliminary estimates of the potential costs to achieve rail cask handling capabilities were developed. These results are based on preliminary analyses using available generic cost data. They represent lower bound values that are useful for developing an initial assessment of the viability of the postulated changes on a system-wide hasis, but are not intended to be absolute values for specific reactors or sites without additional in-depth study.

\subsection{PESIJLTS OF THE DATA REVIEW OF SPENT FIIEL RAIL SHIPPING CASK CAPABILITIES}

This study assumes a slightly different total number of reactors, 127 , compared to the Daling et al. report (1985), which listed a total of 130 reactors. The reasons for this are 1) the preparations for the TMI-2 damaged fuel shipping campaign are dlready underway and 2) the Marhle Hill 1 and 2 units have been canceled. In the TMI-2 case, there is no fuel in their storage pool and restart of the reactor is uncertain; therefore, for purposes of this analysis, the TMI-2 situation is not anticipated to impact fuel movements in the 1995 time frame.

Based on a total population of 127 reactors, the following data are drawn from Table 3.1. 
- Usable rail cask handing capabilities exist at 83 (65\%) of the reactors.

- Preliminary feasibility assessments indicate $12(27 \%)$ of the remaining 44 reactors are incapable of achieving rail cask handling capability without significant changes. The reasons for not considering these reactors further are described in detail in Section 4.3.

- The remaining 32 reactors are the main focus of this study since they are considered potential candidates for achieving rail cask handing capabilities.

- Nineteen of the 83 , or $23 \%$ of the plants with current rail cask capability indicated a preferred rail cask type.

Rail cask handling capability as a function of the number of nuclear plants on a site is shown in Table 4.1. It can be seen from the table that rail cask handling capabilities currently exist on $60 \%$ of the sites with a single reactor, on $79 \%$ of the sites with two reactors, and on $39 \%$ of the sites with three reactors. It should be recognized that cost savings could be realized in the construction of spur tracks on multiple reactor sites. The preliminary cost estimates developed for several plants selected for assessment in this study are affected in this manner (see Appendix B for details).

\section{TABLE 4.1. Rail Cask Capability as a Function of the Number of Reactors on a Site}

\begin{tabular}{|c|c|c|c|}
\hline $\begin{array}{c}\text { Number of } \\
\text { Reactors Onsite }\end{array}$ & $\begin{array}{l}\text { Number } \\
\text { of Sites }\end{array}$ & $\begin{array}{l}\text { Number of Sites } \\
\text { With Rail Cask } \\
\text { Capability to All } \\
\text { Reactors on Site } \\
\end{array}$ & $\begin{array}{l}\text { Percent of Total } \\
\text { Sites with Rail Cask } \\
\text { Capability to All } \\
\text { Reactors on Site }\end{array}$ \\
\hline One & 35 & $? 1$ & 60 \\
\hline Two & 34 & 27 & 79 \\
\hline Three & 8 & 3 & 38 \\
\hline
\end{tabular}

4.2 REACTORS NOT SUBJECTED TO FIJRTHER CONSIDERATION IN THIS STIJPY

The 12 nuclear power plants shown in Table 4.2 were not subjected to further evaluation in this study. Rail capability could potentially be achieved 
at these plants (e.g., with dry cask transfers, heavy haul techniques, etc.), but more reactor-specific information would be necessary before that determination can be finalized.

\subsection{PREL. IMINARY ESTIMATES FOR THE COSTS OF CHANGES AT THE SELECTED REACTORS OF INTEREST}

The 32 reactors chosen for further examination in this study are presented in Table 4.3. Based upon the identified cask handling limitations, evaluations were performed on each of the reactors shown in the table to develop postulated changes that would conceptually result in rail cask handling capabilities at these plants by 1995. These changes are presented for each plant in Appendix $B$. Preliminary cost estimates for the reactors shown in the table were developed utilizing a unit-component approach and are discussed also in Appendix B.

The estimated cost of postulated changes to achieve rail cask handling capabilities at the 32 selected LWRs are summarized in Table 4.4. It can be seen from the table that the cranes at 11 reactors would need to be modified because the cranes are currently rated at about 100 tons. The primary reason for the modifications would be to upgrade the cranes' capacities to safely handle a future cask design which will probably weigh about 100 tons when fully loaded. In all cases it was assumed that crane alterations could be accomplished by replacing the trolley. This modification is expected to incur a nominal cost of about $\$ 1$ million per unit.

Spur track and right-of-way costs vary and the total amount per plant is influenced by a number of factors, including the length of spur track(s), the rail contractor, and the type of terrain (e.g., whether level ground or hilly country must be traversed by the tracks).

It was estimated that expenditures in the range of $\$ 0.2$ million to $\$ 5$ million would be necessary to achieve rail cask capability at each of 16 reactors, $\$ 5$ million to $\$ 10$ million at each of six reactors, and greater than $\$ 10$ million per plant at the remaining six reactors. Four reactors shown in Table 4.4 are connected to their sister units efther by a transfer canal or by sharing a common spent fuel storage pool. It was assumed that the cost of changes at the 


\section{TABLE 4.2. Reactors Not Further Evaluated in this Study}

Plant Name

Big Rock Point

Ft. Calhoun 1

Indian Point 1

Indian Point $2 \& 3$

La Crosse

Point Beach $1 \& 2$

R. E. Ginna

St. Lucie $1 \& 2$

Yankee (Rowe)
Reason(s)

This plant is a single BWR on a site with a cask crane capacity of 24 tons (derated). Length of cask is 1imited by need for adequate (about $8 \mathrm{ft}$ ) water coverage as fuel is inserted into cask. Although it has a spur track onsite leading into the loading bay, significant changes would be required.

This PWR has limited crane capacity; therefore, significant structural changes would probably be required. No spur track exists on the site.

This unit has been retired as an electricity generating facility. Currently, this site has no spur track.

Both units are on the same site. No spur track exists on the site. Both units have a cask crane capacity of 40 tons. Major changes would be required.

This plant is a single BWR on a site with a cask crane capacity of 50 tons. Although it has a spur track on site, it has not been used for several years. Further limitations are due to inadequate cask loading pool dimensions. It is judged that major changes would be required.

Both of these PWR plants use same cask handling crane (currently licensed for 26 ton cask). New cask drop analysis would be required for heavier casks. There may be spent fuel pool structural constraints. Considerabiy more reactor specific information is needed.

This plant is a single PWR on a site with a cask crane capacity of 40 tons. There is no railroad on the site. Significant changes would probably be required.

Both PISR units are on the same isiand site. Currently, there is no spur track onsite and a rail bridge would prohably be required.

This plant is a single PWR on a site with a cask crane capacity of 60 tons (currently derated to 35 tons). The site is in a very hilly area. Inadequate cask loading pool dimensions may be the cause of further 1 imitations. 
TABLE 4.3. Selected LWRs Utilized in this Study

\begin{tabular}{|c|c|}
\hline Plant (Type) & Region (a) \\
\hline $\begin{array}{l}\text { Browns Ferry-1 (BWR) } \\
\text { Browns Ferry-2 (BWR) } \\
\text { Browns Ferry-3 (BWR) } \\
\text { Callaway-1 (PWR) } \\
\text { Calvert Cliffs-1 (PWR) } \\
\text { Calvert Cliffs-2 (PWR) } \\
\text { Connecticut Yankee (PWR) } \\
\text { Crystal River-3 (PWR) } \\
\text { Diablo Canyon-1 (PWR) } \\
\text { Diablo Canyon-2 (PWR) } \\
\text { Hope Creek (BWR) (b) } \\
\text { Kewaunee (PWR) } \\
\text { Oconee-1 (PWR) } \\
\text { Oconee-2 (PWR) } \\
\text { Oconee-3 (PWR) } \\
\text { Oyster Creek (BWR) } \\
\text { Palisades (PWR) } \\
\text { Peach Bottom-2 (BWR) } \\
\text { Peach Bottom-3 (BWR) } \\
\text { Pilgrim-1 (BWR) } \\
\text { Salem-1 (PWR) (b) } \\
\text { Salem-2 (PWR) (b) } \\
\text { San Onofre-1 (PWR) } \\
\text { San Onofre-2 (PWR) } \\
\text { San Onofre-3 (PWR) } \\
\text { Shoreham (BWR) } \\
\text { Surry-1 (PWR) } \\
\text { Surry-2 (PWR) } \\
\text { Trojan (PWR) } \\
\text { Turkey Point-3 (PWR) } \\
\text { Turkey Point-4 (PWR) } \\
\text { wNP-2 (BWR) }\end{array}$ & $\begin{array}{l}\text { S } \\
S \\
S \\
M W \\
N E \\
N E \\
N E \\
S \\
W \\
W \\
N E \\
M W \\
S \\
S \\
S \\
N E \\
M W \\
N E \\
N E \\
N E \\
N E \\
N E \\
W \\
W \\
W \\
N E \\
S \\
S \\
W \\
S \\
S \\
W\end{array}$ \\
\hline
\end{tabular}

\footnotetext{
(a) $\mathrm{NE}=$ Northeast, $\mathrm{S}=$ South, $M W=$ Midwest, and $W=$ West.

(b) Hope Creek, Salem-1 and Salem-2 are on the same site.
}

first unit was the total cost involved for both units, since one rail spur would be used for access to both units. In general, the major contributor to the total cost for individual plants within each of these groups is the length of the spur track that would need to be constructed. Details of the preliminary cost estimates for the plants shown in Table 4.4 are presented in 


\section{TABLE 4.4. Estimated Costs of Changes to Achieve Rail Cask Capability at the Selected LWRs Utilized in this Study $(a)$}

\begin{tabular}{l} 
Plant (Type) \\
\hline Browns Ferry-1 (BWR) \\
Browns Ferry-2 (BWR) \\
Browns Ferry-3 (BWR) \\
Callaway-i (PWR) \\
Calvert Cliffs-1 (PWR) \\
Calvert Cliffs-2 (PWR) \\
Connecticut Yankee (PWR) \\
Crystal River-3 (PWR) \\
Diablo Canyon-1 (PWR) \\
Diablo Canyon-2 (PWR) \\
Hope Creek (BWR) (e) \\
Kewaunee (PWR) \\
Oconee-1 (PWR) \\
Oconee-2 (PWR) \\
Oconee-3 (PWR) \\
Oyster Creek (BWR) \\
Palisades (PWR) (g) \\
Peach Bottom-2 (BWR) \\
Peach Botton-3 (BWR) \\
Pilgrim-1 (RWR) \\
Salem-1 (PWR) (e) \\
Salem-2 (PWR)(e) \\
San Onofre-1 (PWR) \\
San Onofre-2 (PWR) \\
San onofre-3 (PWR) \\
Shoreham (BWR) (g) \\
Surry-1 (PWR) \\
Surry-2 (PWR) \\
Trojan (PWR) \\
Turkey Point-3 (PWR) \\
Turkey Point-4 (PWR) \\
WNP-2 (BWR)
\end{tabular}

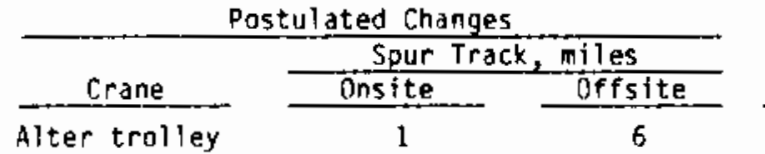

(d)

Alter trolley

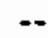

$--$

(d)

Alter trolley

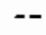

$--$

$--$

$--$

$--$

Alter trolley

(f)

Alter trolley

Alter troliey

Alter trolley

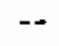

$--$

Alter trolley

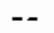

$+$

Alter trolley

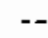

$\rightarrow$

$--$

$\ldots$

(f)

-

Aiter trolley

Alter trolley
-.

1

1

1

1

$--$

1

1

$$
1
$$

\section{1}

$$
1
$$

1

1

$$
--
$$

$$
1
$$

1

$$
1
$$

$$
1 \text { (repair) }
$$$$
1 \text { (repair) }
$$

\author{
Estimated \\ Cost, Millions \\ (1984 dollars) (h,c) \\ 7.14
}

$+$

--

$--$

1.80

-. 0.41

$39 \quad 35.35$

--

9

$=$

9.75

0.41

$19 \quad 17.06$

$\begin{array}{ll}- & 0.41\end{array}$

-- 0.41

$4 \quad 4.01$

$9 \quad 9.75$

-- ..

$\begin{array}{ll}-- & 1.80\end{array}$

$14 \quad 14.10$

-. 1.80

1.80

-- 0.41

$9 \quad 9.75$

$14 \quad 12.71$

-. 0.41

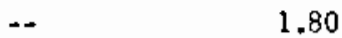

-- 0.41

$\rightarrow \quad 0.41$

$9 \quad 8.36$

2522.29

-- - -

-- 0.41

$9 \quad 9.75$

-- 1.80

$\begin{array}{ll}- & 0.21\end{array}$

(a) Cranes rated at approximately 100 tons (see Tahle 3.1 for details) are assumed to be upgraded to about 125 tons to safely handle the future cask design weighing about 100 tons as discussed in Section 3.1 .

(b) The number of figures shown is for computational accuracy and does not imply precision to that inany significant figures. Details of reactor-specific cost estimates are contained in Appendix $R$.

(c) includes $25 \%$ contingency.

(d) No crane modifications required; pool connected by transfer canal to Unit 1.

(e) Hope Creek, Salem 1 , and Salem 2 are on the same site.

(f) No crane modifications required; common pool shared with unit 1.

(g) Adtitional information is needed to confirm that the dimensions of the cask loading pool can accommodate a large rail cask. 
Appendix B. Because of the length of the spur track needed for the Calvert Cliffs site, it was estimated to be the most costly project at about $\$ 35$ miliion.

The development of the unit-component costs utilized in this study are discussed in Appendix $A$. In addition, other factors are identified (but not quantified) in Appendix $A$ that could substantially affect the reactor-specific cost estimates shown in Table 4.4. The reader is cautioned that due consideration must be given to the factors discussed in Appendix $A$, since they have the potential for significantly impacting the total costs of many of the projects evaluated in this study. 
$?$

,

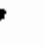

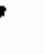

. 


\subsection{OBSERVATIONS AND COMMENTS}

The postulated changes that would result in rail cask handing capabilities at selected LWRs are preliminary in nature. Site-specific licensing and hardware issues will have to be addressed in every case where this capability is desired. To identify all the practical aspects involved in each such assessment would require an in-depth study of each plant since each reactor and its respective site are unique. Such a level of detail was beyond the scope of this study.

Only after detailed studies are completed will it be possible to determine those reactors where cost-effective measures could meet with success in a timely manner. In all cases, however, defining and understanding the sources of the various cost elements, including the time frames associated with these elements is essential. As recent events in the nuclear industry have clearly illustrated, if costs cannot be defined (controlled), the schedule cannot be controlled. A generic list of some major cost elements might include the followirg:

- corstruction of $x$-miles of railroad track (and consideration given to sursequent maintenance thereof)

- onsite structural changes required

- regulatory requirements including various associated reviews

- potential disruption of plant operations

- plenning, scheduling, and training required for the shipping campaign (including dry runs and testing of equipment).

For most of the items described above, contracts, schedules, license changes, and permitting must be addressed. The cost issues associated with each element must be identified and discussed from different points of view so that all the potential problems and their respective solutions are understood. 
The potential use of heavy haul techniques(a) was not within the scope of this study; however, these alternatives should be investigated as a means of achieving rail access capability while averting rail spur additions and laying new track.

(a) Heavy-haul is the transport of overweight or overdimension cargo that requires special equipment. These types of shipments are often associated with intermodal shipments where a heavy rail cask is transported by heavyhaul truck to a rail siding (for plants that do not have rail access but wish to use rail casks) or barge slip. An intermodal shipment is defined as a shipment that is performed using two or more transport modes. 


\section{REFERENCES}

Best, R. E., et al. 1977. Capabilities of U.S. Domestic Transportation Systems for the Shipment of Radioactive Waste. NAC C-7715, Nuclear Assurance Corporation, Prepared for the U.S. Energy Research and Development Administration, Washington, D.C.

Daling, P. M., et al. 1985. Spent Nuclear Fuel Shipping Cask Handling Capabilities of Commercial Light Water Reactors. PNL-5384, Pacific Northwest Laboratory. Richland, Washington. 
$-$

$+$

.

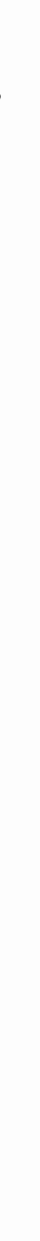


APPENDIX A

COST ESTIMATING BASES 
APPENDIX A

\section{COST EST IMATING BASES}

The cost information developed in this study is based on unit cost data presented in this appendix. Categories for which generic cost data are given include: spur track and right-of-way, cask handling cranes, licensing costs, and contingency allowance. Equipment costs are estimated using published information and/or information based on contacts with equipment vendors, as appropriate. The data are presented in late-1984 dollars.

To ensure the applicability of the unit costs presented in this appendix to any specific situation, the reader is cautioned that the data should be carefully examined and adjusted as necessary with due consideration given to the miscellaneous factors discussed in Section A.5.

\section{A.1 RAILROAD SPUR TRACK AND RIGHT -OF -WAY COSTS}

Railroad spur track costs used in this study are as follows: $\$ 50-\$ 60 /$ lineal foot for onsite track, assuming above sub-grade and at ground level; up to $\$ 200 / 1$ ineal foot for offsite track in rough terrain. For purposes of the cost estimates developed in this study, it is assumed that all onsite work is at the $\$ 60 / \mathrm{LF}$ rate and all offsite work is at an average cost of $\$ 130 / \mathrm{LF}$ rate. Both rates include ballast, ties, and rail. Other factors affecting costs include the following:

- For longer runs, economies of scale (i.e., somewhat lower cost/LF) could be negotiated.

- In general, a rail contractor (not the railroad company itself) does the work off railroad company property. The railroads use their own personnel if work is done on their own property. In addition, the length of the runs helps determine the contractor (i.e., there are small and large contractors, depending on the size of the project). 
- The construction of bridges, if required, are neglected in this analysis. Site-specific analyses are needed to determine this factor and are beyond the scope of this study.

- It is assumed that $50 \mathrm{ft}$ wide runs of single track are used. This allows for ditching, communications, etc.

- Right-of-way 1and costs are based on \$1000/acre; thus, for a $50 \mathrm{ft}$ wide strip one mile long the cost is estimated at $\$ 10,000 / 1$ ineal mile. There is no cost for land at the reactor site. It is also assumed, unless stated otherwise, that the distance from the cask handing facilities to the reactor site property line is one mile.

\section{A.2 CRANE COSTS}

The primary assumptions associated with crane costs used in this study are as follows:

1. In the alteration or conversion of an existing crane or the replacement of an existing crane to provide the postulated rail cask handling capability, the overall acceptability (including that of unreplaced structures and components) must be demonstrated by the ficensee.

2. PWRs and BWRs use similar cranes to handle spent fuel shipping casks in their respective fuel handling facilities. For this analysis, the following costs are considered "typical:"

\begin{tabular}{|c|c|}
\hline Item & Estimated Cost (1984\$) \\
\hline Trolley replacement & $\$ 750 K \pm 15 \%$ \\
\hline Whole crane replacement & $\$ 1 M \pm 15 \%$ \\
\hline Installation & $\$ 150 K-\$ 450 K$ \\
\hline Materials & $\begin{array}{l}\$ 10 \mathrm{~K} \text { - } \$ 50 \mathrm{~K} \text {, depending on radiation zone } \\
\text { conditions as well as other factors }\end{array}$ \\
\hline
\end{tabular}

3. In general, spent fuel cask cranes are nonstandard design. This is primarily due to different seismic criteria, which in turn is based 
on geographic location. Such cranes are designated as a Seismic Class I item of equipment because they are required to perform certain critical functions in the nuclear power plant.

4. Installation, testing, etc. assumes no reactor downtime.

\section{A.3 REGULATORY CLIMATE AND ESTIMATED LICENSING COSTS}

In planning for and carrying out site and/or facility modifications, the licensee must be aware of all regulations pertaining to these activities and how they will affect operations as well as the associated costs of these activities. Of direct interest to the 1 icensees contemplating changes affecting their license, for example, is the NRC licensing fee schedule. The reason for this is that with the recent (May 21, 1984) revision to 10 CFR 170 , the NRC has established a policy of full cost recovery for all NRC activities associated with amendments, renewal, dismantling activities, and termination of reactor licenses. In those cases where license amendments must be performed, this implies reactor specific 1) reviews, 2) safety evaluations, 3) significance and hazards analyses, 4) Federal Register Notices and publishing costs, 5) legal and management reviews, etc.

Since there has been little or no experience with certain kinds of licensing activities with the $N R C$, it is difficult to predict with any precision what various costs delineated in this study might be in the 1995 time frame.

For the purposes of this analysis, it is assumed that the completeness and the quality of the licensee's submittals for complex projects are such that one NRC staff-year is required to accomplish the appropriate reviews, operational surveillance, and required inspections. The estimated cost of one person-year in 1984 dollars is about $\$ 110,000$. This amount represents a minimum estimate. Should the submittals be incomplete, or should other difficulties (undefined) he encountered, this estimated cost could increase significantly.

It is assumed further that the licensee could incur costs in the range of $\$ 10,000$ to greater than $\$ 100,000$ for plant-specific studies and analyses 
associated with their postulated changes (e.g., rail access study and technical evaluations). Again, this amount varies depending on the complexity of the project.

Licensing-related activities, such as public relations, public hearings and state and local agency controls are activities that would normally be handled as part of a spent fuel shipping campaign. NRC licensing-type activities are all performed by the utility and the direct costs may be difficult to segregate. It is assumed that the utility will collect all the costs as separate accounts in the reactor's project expenses that are related to the licensing aspects of a spent fuel shipping campaign and to public and institutional activities.

\section{A. 4 RATIONALE FOR THE CONTINGENCY ALLOWANCE IISEO IN THIS STIIDY}

Other factors can affect costs of changes such as climate (which can affect the cost of power, water, etc.), contractor management, regulatory requirements, and availability and deliverability of materials and supplies (including rail track and cranes or parts thereof). These factors and those discussed previously in this appendix, while difficult to evaluate, are not solely dependent on the section of the country where the work takes place. In combination, these factors result in uncertainties that are unavoidable and, depending on the size of the project, can be important contributors to the total project cost. These case-specific factors have to be addressed through the application of judgment during the planning and preparation stage of the specific project to assure that adequate contingency is provided. It should be recognized that on a case-by-case hasis contingency could he significant. What follows is a discussion of the nature of a contingency allowance, the variation in the size of the contingency allowance as a function of the degree of knowledge about the project, and the average size of the allowance assumed for the feasibility assessments developed in this study.

A common element of engineering cost estimates is contingency. The Nmerican Association of Cost Engineers (AACE) describes contingency as: 
"The specific provision for unforeseeable elements of cost within the defined project scope; particularly important where previous experience relating estimates and actual costs has shown that unforeseeable events which will increase cost are likely to occur ..."

Unfortunately, there is no common definition which specifies all items that may be included in contingency.

Because of the varying circumstances that make a contingency necessary, a single standard rate is not appropriate for all situations. The rate could be as high as $100 \%$ of the cost for an untried process where engineering is not complete and the job is to take place in the distant future. Contingency amounts of 20 to $35 \%$ are not uncommon for projects in the proposal stages. Contingency amounts of $5 \%$ are not uncommon for projects that have been fully engineered and designed and are entering the construction phase.

A contingency allowance of $25 \%$ was used in this study. This considers the state of knowledge available for the reactor-specific projects examined in this study that are to take place 5 to 10 years in the future.

\section{A. 5 MISCELLANEOUS FACTORS}

The most potentially significant cost element not addressed in this study is the amount of plant downtime that could he associated with the various changes postulated to provide rail cask capahility at the selected plants of interest. Again, this element would have to be addressed on a case-by-case basis.

Several other factors more difficult to quantify genericaliy should be recognized for their potential impact on costs and for the need to consider them on a case-by-case basis. These factors are discussed briefly in the following subsections.

\section{A.5.1 Deteriorating Railroad Tracks}

Several reactor-specific rail spur tracks are known to be in various states of disrepair (see Appendix B for details). This situation can only worsen between now and 1995. The ultimate impact this situation could have on plant-specific spent fuel shipping campaigns is not addressed here. However, 
this is an area that could be examined for its potential impact on selected shipments planned for the 1995 time frame.

\section{A.5.2 Equipment Onsolescence}

Cranes that might be replaced at selected reactors may have substantial salvage value or could possibly be used at other facilities or instaliations. Where site-specific studies indicate crane or trolley replacement is needed to provide rail cask handling capability, near-tem replacement of the existing crane could possibly generate some cost benefits. As time goes on this option would likely decrease in value due to either obsolescence or general deterioration. In fact, suhstantial additional costs might he incurred to replace or update the equipment at a later time should the licensee delay in taking this action.

\section{A.5.3 Engineering and Planning Costs for Shipment by Rail}

Some plant owners may not have sufficient in-house staff to accomplish some of the postulated changes detemined to he necessary to achieve rail cask capahility. Therefore, they may choose to employ consultants and outside engineering firms to perfom the engineering and planning for shipment of spent fuel by rail. With or without this expertise, these costs could he significant on a plant-specific basis. However, such cost estimates are beyond the scope of this study. It is suggested that this effort be estimated for both the in-house approach and the external contractor approach in order to determine the methor that provides the greatest incremental cost savings.

\section{A.5.4 Site Layout}

Site layouts of all the reactors considered in this study need to he examined carefully. The reason for this is that there could be some buildings or other structures near the plants that could preclude or greatly increase the costs of construction of a spur track at certain sites. 
APPENDIX B

PRELIMINARY COST ESTIMATES

FOR 32 SELECTED LWRS 
APPENDIX B

PREL IMINARY COST ESTIMATES

FOR 32 SELECTEO LWRS

Based on the cost infomation presented in Appendix A, cost estimates of postulated changes for 32 selected LWRs were developed. The individual estimates for those nuclear power plants are presented in this appendix. The data are presented in alphabetical order according to the plant name. Additional cask handling information presented for each of the plants was extracted from the Daling et al. report (1985) and is included in this appendix for completeness.

In light of other inherent, pervasive and site-specific uncertainties, the reader is cautioned against applying the cost estimates presented in this appendix to the actual plants without additional in-depth study. For example, it was not within the scope of this study to probe in detail all of the actual cask loading bay/building changes which could be necessary to accommodate the various size rail casks. Complex issues are involved in each case and the preliminary results presented in this appendix should not be considered final. These cost estimates are provided solely as baseline information and are subject to major changes upon receipt of additional site-specific details.

In the following appendix, the term "Pool" is used to describe two different items. "Pool" refers to the spent fuel storage pool when the parameter "Share Pool" is called out. It refers to the cask loading pool (which may or may not be separated from the spent fuel storage pool) when the parameters "Pool Depth," "Pool Width," and "Pool Length" are called out. At some reactors, cask loading pool use may he restricted to certain cask designs because of loading pool dimensional constraints. This will have to he determined on a case-by-case hasis.

Some example calculations used for the spur track cost estimates given in this appendix are as follows:
a) $\$ 60 /$ LF $(5280 \mathrm{ft} / \mathrm{mile})$
$=\$ 0.32 M / m i l e$, onsite track
b) $\$ 130 / \mathrm{LF} \quad(5280 \mathrm{ft} / \mathrm{mile})$
$=\$ 0.69 \mathrm{M} / \mathrm{mile}$, offsite track
c) $810 \mathrm{~K} / \mathrm{mi} 1 \mathrm{e}$
$=\$ 0.01 \mathrm{M} / \mathrm{mile}$, right-of-way 
Plant Name: Browns Ferry-1

Utility: Tennessee Valley Authority

Nearest Town: Decatur, AL

NRC Docket Number: 50-259

Reactor Type: BWR

Rating: (a) 1067 MWe

In Plant Handling Parameters:

Share Pool: (b) B

Preferred Cask:

Cask Experience: None

Cask Crane Capacity, tons: 106

Crane height, ft: ${ }^{(\mathrm{C}}$

Pool Depth, ft: (d) 39

Pool Width, ft: (d) 8

Pool Length, ft: (d) 8

Comments: 67 ton cask has been analyzed for use at Browns Ferry.

ESTIMATED COSTS OF THIS PROJECT

Estimated Costs,

Cost Category

in Millions of

1984 Dollars

\section{Changes:}

Spur track:

a) 1 mile(s) track, nnsite 0.32

b) -6 mile(s) track, offsite 4.12

c) 6 mile(s) right-of-way offsite 0.06

d) other--studies

0.10

Subtotal

4.60

Cask Handling Crane:

e) Alter trolley (replacement) 0.8

f) Installation and Materials 0.2

g) Other

Subtotal

1.0

NRC Licensing Costs

0.11

Contingency (25\%)

Total, Changes

$\frac{1.43}{7.14}$

(a) Spent Fuel Reguirements, D0E/RL-84-1, May 1984.

(b) $\bar{A}$ indicates common pool shared by two reactors.

$B$ indicates pools connected by transfer canal.

$C$ indicates pools connected by cask transfer.

(c) The distance from the operating deck to the bottom of the crane hook at its uppermost position.

(d) Refers to the respective usable dimension (i.e., length, width, or depth) of the cask loading well. 
Plant Name: Browns Ferry-2

Utility: Tennessee Valley Authority

Nearest Town: Decatur, AL

NRC Docket Number: 50-260

Reactor Type: BWR

Rating: (a) 1067 MWe

In Plant Handing Parameters:

Share Pool: (b) B

Preferred Cask:

Cask Experience: None

Cask Crane Capacity, tons: 106

Crane height, ft:

Pool Depth, ft: (d) 39

Pool Width, ft: (d) 8

Pool Length, ft: (d) 8

Comments: See comments, Browns Ferry-1.

\section{ESTIMATED COSTS OF THIS PROJECT}

Comments: Browns Ferry 1 and 2 pools are connected by a transfer canal; therefore, only the crane for Init 1 is altered and only a single spur track is assumed for purposes of this cost estimate.

(a) Spent Fuel Requirements, D0E/RL-84-1, May 1984.

(b) A indicates common pool shared by two reactors.

$B$ indicates pools connected by transfer canal.

$C$ indicates pools connected by cask transfer.

(c) The distance from the operating deck to the bottom of the crane hook at its uppermost position.

(d) Refars to the respective usable dimension (i.e., length, width, or depth) of the cask loading well. 
Plant Name: Browns Ferry-3

Utility: Tennessee Valley Authority

Nearest Town: Decatur, AL

NRC Docket Number: 5D-296

Reactor Type: BWR

Rating: (a) 1067 MWe

In Plant Handling Parameters:

Share Pool: (b) No

Preferred Cask:

Cask Experience:

Cask Crane Capacity, tons: 106

Crane height, $f t:(c)$

Pool Depth, ft: (d) 39

Pool Width, ft: (d) 8

Pool Length, ft: (d) 8

Comments: See comments, Browns Ferry-1.

ESTIMATED COSTS OF THIS PROJECT

Estimated Costs, in Millions of

Cost Category 1984 Dollars

Changes:

Spur track:

a) 1 mile(s) track, onsite

0.32

b) mile(s) track, offsite

c) mile(s) right-of-way offsite

d) סther--study

Subtotal

$\frac{0.01}{0.33}$

Cask Handing Crane:

e) Alter trolley (replaceinent) 0.8

f) Installation and Materials 0.2

g) Other

Subtotai

1.0

NRC Licensing Costs

0.11

Contingency (25\%)

Total, Changes

$\frac{0.36}{1.80}$

(a) Spent Fuel Requirements, D0E/RL-84-1, May 1984.

(b) A indicates common pool shared by two reactors.

$B$ indicates pools connected by transfer canal.

$C$ indicates pools connected by cask transfer.

(c) The distance from the operating deck to the bottom of the crane hook at its uppermost position.

(d) Refers to the respective usable dimension (i.e., length, width. or repth) of the cask loading well. 
Plant Name: Callaway-1

Utility: Union Electric Company

Nearest Town: Fulton, M0

NRC Docket Number: 50-483

Reactor Type: PWR

Rating: (a) 1166 MWe

In Plant Handling Parameters:

Share Pool: (b) No

Preferred Cask: None Specified

Cask Experience:

Cask Crane Capacity, tons: 150

Crane height, ft: (c) 31.3

Pool Depth, ft: (d) 44.3

Pool Width, ft: (d) 16.0

Pool Length, ft: (d) 18.0

Comments: Upper floor limit is 1000 psf.

ESTIMATED COSTS OF THIS PROJECT

Estimated Costs,

in Millions of

Cost Category

1984 Dollars

Changes:

Spur track:

a) $1 \mathrm{mile}(\mathrm{s})$ track, onsite

0.32

b) mile(s) track, offsite

c) mile(s) right-of-way of site

d) $\overline{\text { ther--study }}$

0.01

Subtotal

0.33

Cask Handling Crane:

e) Alter trolley (replacement)

f) Installation and Materials

g) Other

Subtota?

NRC Licensing Costs

Contingency (25\%)

Total, Changes

$\frac{0.08}{0.41}$

(a) Spent Fuel Requirements, DOE/RL-84-1, May 1984.

(b) A indicates common pool shared by two reactors.

$B$ indicates pools connected by transfer canal.

$C$ indicates pools connected by cask transfer.

(c) The distance from the operating deck to the bottom of the crane hook at its uppermost position.

(d) Refers to the respective usable dimension (i.e., length, width, or depth) of the cask loading well. 
Plant Name: Calvert Cliffs-l

Utility: Baltimore Gas and Electric Co.

Nearest Town: Lusby, MD

NRC Docket Number: 50-317

Reactor Type: PWR

Rating: (a) $825 \mathrm{MWe}$

In Plant Handing Parameters:

Share Pool: (b) B

Preferred Cask: NLI 1/2

Cask Experience: NAC-1, NFS-4, NLI $1 / 2$

Cask Crane Capacity, tons: 150

Crane height, $\mathrm{ft:}(\mathrm{C}) \quad 35$

Pool Depth, ft: (d) 41

Pool Width, ft: (d) 9

Pool Length, ft: (d) 11

Comments: Currently limited by FSAR cask drop analysis to 25 ton class casks.

ESTIMATED COSTS OF THIS PROJECT

Estimated Costs, in Millions of

Cost Category 1984 Dollars

Changes:

Spur track:

a) 1 mile(s) track, onsite 0.32

b) 40 mile(s) track, offsite 27.46

c) $40 \mathrm{mile}(\mathrm{s})$ right-of-way of fsite 0.40

d) other--studies

0.10

Subtotal

28.28

Cask Handling Crane:

e) Alter trolley (replacement)

f) Installation and Materials

g) Other

Subtotal

NRC Licensing Costs

Contingency (25\%)

Total, Changes

(a) Spent Fuel Requirements, DOE/RL-84-1, May 1984 .

(b) A indicates common pool shared by two reactors.

$B$ indicates pools connected by transfer canal.

$C$ indicates pools connected by cask transfer.

(c) The distance from the operating deck to the bottom of the crane hook at its uppermost position.

(d) Refers to the respective usable dimension (i.e., length, width, or depth) of the cask loading well. 
Plant Name: Calvert Cliffs-2

Utility: Baltimore Gas and Electric Co.

Nearest Town: Lusby, MD

NRC Docket Number: 50-318

Reactor Type: PWR

Rating: (a) $825 \mathrm{MWe}$

In Plant Handling Parameters:

Share Pool: (b) B

Preferred Cask: NLI $1 / 2$

Cask Experience: NAC-1, NFS-4, NLI $1 / 2$

Cask Crane Capacity, tons: 150

Crane height, ft: (c) 35

Pool Depth, ft: (d) 41

Pool Width, ft: (d) 9

Pool Length, ft: (d) 11

Comments: See comments, Calvert Cliffs-1

\section{ESTIMATED COSTS OF THIS PROJECT}

Comments: Calvert $\mathrm{Cliffs} 1$ and 2 pools are connected by transfer canal; therefore, only a single spur track is assumed for purposes of this cost estimate.

(a) Spent Fuel Requirements, DOE/RL-84-1, May 1984.

(b) A indicates common pooT shared by two reactors.

$B$ indicates pools connected by transfer canal.

$C$ indicates pools connected by cask transfer.

(c) The distance from the operating deck to the bottom of the crane hook at its uppermost position.

(d) Refers to the respective usable dimension (i.e., length, width, or depth) of the cask loading well. 
Plant Name: Connecticut Yankee

Utility: Northeast Utilities

Nearest Town: Haddam Neck, CT

NRC Docket Number: 50-213

Reactor Type: PWR

Rating: (a) 582 MWe

In Plant Handling Parameters:

Share Pool: (b) No

Preferred Cask: None

Cask Experience: IF-200, NAC-1

Cask Crane Capacity, tons: 100

Crane height, ft: ${ }^{(c)} 28$

Pool Depth, ft: (d) 35

Pool Width, ft: (d) 6.5

Pool Length, ft: (d) 6.5

Comments: Information from FSAR not yet verified. 83 bundles were sent offsite 7-8 years ago.

ESTIMATED COSTS OF THIS PROJECT

Estimated Costs,

Cost Category in Millions of 1984 Dollars

Changes:

Spur track:

a) 1 mile(s) track, onsite 0.32

b) 9 mile(s) track, offsite 6.18

c) $\overline{9}$ mile(s) right-of-way of fsite 0.09

d) तुther--studies $\quad 0.10$

Subtotal

6.69

Cask Handling Crane:

e) Aiter trolley (replacement) 0.8

f) Installation and Materials 0.2

g) Other

Subtotal

1.0

NRC Licensing Costs

Contingency (25\%)

Total, Changes

0.11

$\frac{1.95}{9.75}$

(a) Spent Fuel Requirements, DOE/RL-84-1, May 1984 .

(b) A indicates common pool shared by two reactors.

8 indicates pools connected by transfer canal.

$C$ indicates pools connected by cask transfer.

(c) The distance from the operating deck to the botton of the crane hook at its uppermost position.

(d) Refers to the respective usable dimension (i.e., length, width, or depth) of the cask loading well. 
Plant Name: Crystal River-3

Utility: Florida Power Corporation

Nearest Town: Red Level, FL

NRC Docket Number: 50-302

Reactor Type: PWR

Rating: (a) 836 MWe

In Plant Handling Parameters:

Share Pool: (b) No

Preferred Cask: Truck

Cask Experience: NAC-1

Cask Crane Capacity, tons: 120

Crane height, ft: (c) 30.7

Pool 0epth, ft: (d) 43.7

Pool width, ft: (d) 10.0

pool Length, ft: (d) 10.0

Comments: Hatchsize is $35.7^{\prime} \times 8.6^{\prime}$. Have only once used a cask: shipped an NAC-1 single element cask to 0conee, FL in 1977. More than likely to ship hy truck.

\section{ESTIMATEN COSTS OF THIS PROJECT}

Estimated Costs, in Millions of

Cost Category 1984 Dollars

Changes:

Spur track:

a) 1 mile(s) track, onsite 0.32

b) mile(s) track, offsite

c) mile(s) right-of-way of site

d) other--study

$\underline{0.01}$

Subtotal

0.33

Cask Handling Crane:

e) Alter trolley (replacement)

f) Installation and Materials

g) Other

Subtotal

NRC Licensing Costs

Cont ingency (25\%)

Total, Changes

$\frac{0.08}{0.41}$

(a) Spent Fuel Requirements, DOE/RL-84-1, May 1984.

(b) A indicates common poot shared by two reactors.

B indicates pools connected by transfer canal.

$C$ indicates pools connected by cask transfer.

(c) The distance from the operating deck to the hottom of the crane hook at its uppermost position.

(d) Refers to the respective usable dimension (i.e., length, width, or depth) of the cask loading well. 
Plant Name: Diablo Canyon-1

Utility: Pacific Gas and Electric Co.

Nearest Town: Avila Beach, CA

NRC Docket Number: 50-275

Reactor Type: PWR

Rating: (a) 1086 MWe

In Plant Handling Parameters:

Share Pool: (b) No

Preferred Cask: IF-300

Cask Experience: None

Cask Crane Capacity, tons: 125

Crane height, ft: (c) 29.8

Pool Oepth, ft: (d) 45.5

Pool Width, ft: (d) 10.0

Pool Length, ft: (d) 10.0

Comments: Units 1 and 2 are identical, except opposite handed. See comments; Diablo Canyon-2.

\section{ESTIMATED COSTS OF THIS PROJECT}

Estimated Costs, in Millions of

Cost Category 1984 Dollars

Changes:

Spur track:

a) $1 \mathrm{mile}(\mathrm{s})$ track, onsite 0.32

b) 19 mile(s) track, offsite 13.04

c) $19 \mathrm{mile}(\mathrm{s})$ right-of-way offsite 0.19

d) Other--studies

0.10

Subtotal

13.65

Cask Handling Crane:

e) Alter trolley (replacement)

f) Installation and Materials

g) Other

Subtotal

NRC Licensing Costs

Cont ingency $(25 \%)$

Tota1, Changes

$\frac{3.41}{17.06}$

(a) Spent Fuel Requirements, DOE/RL-84-1, May 1984.

(b) $\mathrm{A}$ indicates common pool shared by two reactors.

$B$ indicates pools connected by transfer canal.

$C$ indicates pools connected by cask transfer.

(c) The distance from the operating deck to the bottom of the crane hook at its uppermost position.

(d) Refers to the respective usable dimension (i.e., length, width, or depth) of the cask loading well. 
Plant Name: Diablo Canyon-2

Utility: Pacific Gas and Electric Co.

Nearest Town: Avila Beach, CA

NRC Docket Number: 50-323

Reactor Type: PWR

Rating: (a) 1119 MWe

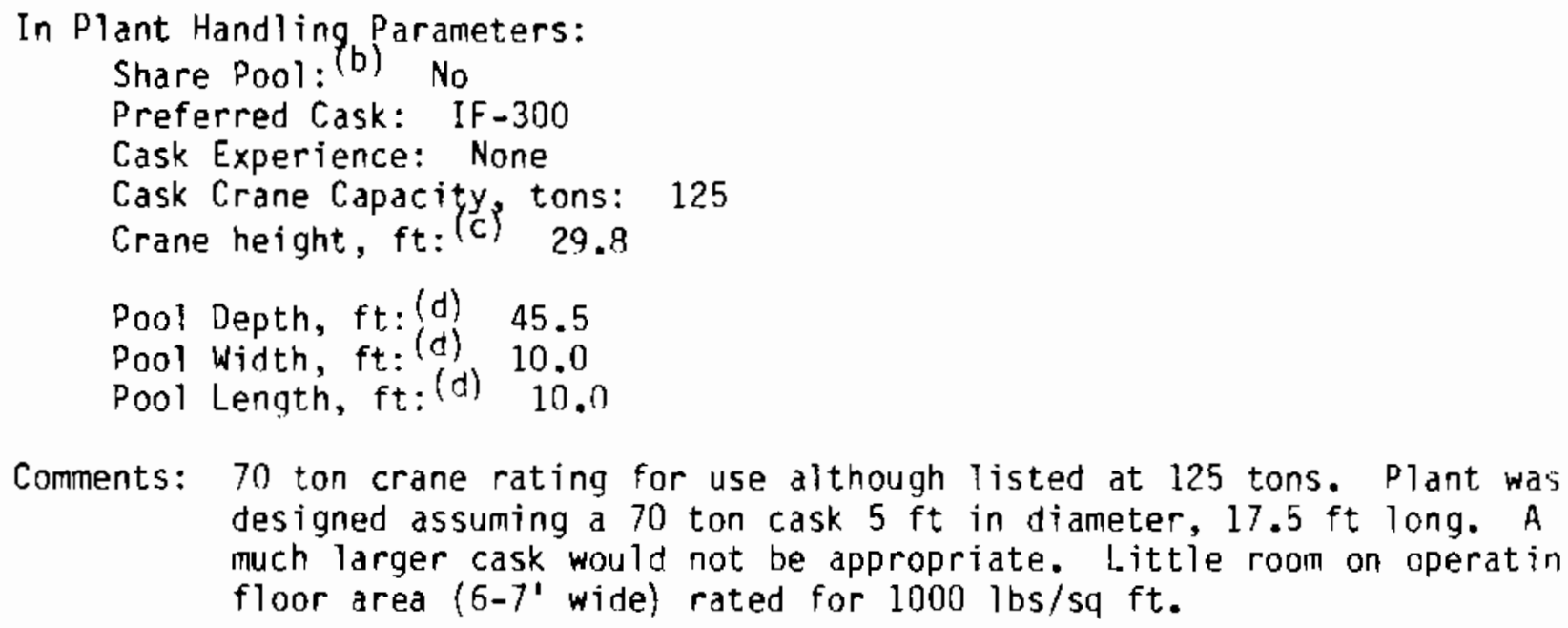

In Plant Handling Parameters:

Share Pool: (b) No

Preferred Cask: IF-300

Cask Experience: None

Cask Crane Capacityy, tons: 125

Crane height, ft: ${ }^{(C)} 29.8$

Pool Depth, ft: (d) 45.5

Pool Width, ft: (d) 10.0

Pool Length, ft: (d) 10.0

Comments: 70 ton crane rating for use although listed at 125 tons. Plant wa's designed assuming a 70 ton cask $5 \mathrm{ft}$ in diameter, $17.5 \mathrm{ft}$ long. A much larger cask would not be appropriate. Little room on operatin floor area (6-7' wide) rated for $1000 \mathrm{lbs} / \mathrm{sq} \mathrm{ft}$.

\section{ESTIMATED COSTS OF THIS PROJECT}

\section{Cost Category}

Estimated Costs, in Millions of 1984 Dollars

Changes:

Spur track:

a) 1 mile(s) track, onsite

b) mile(s) track, offsite

c) mile(s) right-of-way offsite

d) তther--study

0.01

Subtotal

0.33

Cask Handling Crane:

e) Alter trolley (replacement)

f) Installation and Materials

g) Other

Subtotal

NRC Licensing Costs

Contingency (25\%)

Tota1, Changes

(a) Spent Fuel Requirements, D0E/RL-84-1, May 1984.

(b) A indicates common pont shared by two reactors. $B$ indicates pools connected by transfer canal. $C$ indicates pools connected by cask transfer.

(c) The distance from the operating deck to the bottom of the crane hook at its uppermost position.

(d) Refers to the respective usable dimension (i.e., length, width, or depth) of the cask loading well. 
Plant Name: Hope Creek-1

Utility: Public Service Electric and Gas Co.

Nearest Town: Salem, NJ

NRC Docket Number: 50-354

Reactor Type: BWR

Rating: (a) 1067 MWe

In Plant Handling Parameters:

Share Pool: (b) No

Preferred Cask:

Cask Experience:

Cask Crane Capacity, tons: 150

Crane height, $\mathrm{ft}:(\mathrm{c})$ *

Pool Depth, ft: (d) 45.0

Pool Width, ft: (d) 11.0

Pool Length, ft: (d) 11.0

Comments: Scheduled for commercial operation in fall of 1986. *Although crane height was not known, it is great enough to allow the handling of an IF -300 cask.

Estimated Costs, in Millions of

Cost Category 1984 Dollars

Changes:

Spur track:

a) 1 mile(s) track, onsite 0.32

b) mile(s) track, offsite

c) mile(s) right-of-way offsite

d) Other--study

$\underline{0.01}$

Subtotal

0.33

Cask Handling Crane:

e) Alter trolley (replacement)

f) Installation and Materials

g) Other

Subtotal

NRC Licensing Costs

Contingency (25\%)

Tota!, Changes

(a) Spent Fuel Requirements, D0E/RL-84-1, May 1984.

(b) A indicates common poot shared by two reactors.

$B$ indicates pools connected by transfer canal.

$C$ indicates pools connected by cask transfer.

(c) The distance from the operating deck to the bottom of the crane hook at its uppermost position.

(d) Refers to the respective usable dimension (i.e., length, width, or depth) of the cask loading well. 
Plant Name: Kewaunee

Utility: Wisconsin Public Service Corporation

Nearest Town: Carlton, WI

NRC Docket Number: 50-305

Reactor Type: PWR

Rating: (a) 520 MWe

In Plant Handling Parameters:

Share Pool: (b) No

Preferred Cask:

Cask Experience: None

Cask Crane Capacity, tons: 125

Crane height, ft: (c) 29.6

Pool Depth, ft: (d) 40.8

Pool Width, ft: (d) 9.5

Pool Length, ft: (d) 9.5

Comments: 0ctagonal bearing plate in pool measures $9.5^{\prime}$ from flat to flat on octagon. Pool actually measures 17.2' $\times 18.9^{\prime}$. Plant was designed to handle 40 ton truck cask or 110 ton rail cask. Weight is probably 1 imited by overhead crane capacity of 125 ton.

\section{ESTIMATED COSTS DF THIS PROJECT}

Estimated Costs, in Millions of

Cost Category

1984 Dollars

Changes:

Spur track:

a) 1 mile(s) track, onsite 0.32

b) 4 mile(s) track, offsite 2.75

c) 4 mile(s) right $\rightarrow$ of -way of fsite 0.04

d) Dther--studies 0.10

Suhtotal 3.21

Sask Handling Crane:

e) Alter trolley (replacement)

f) Installation and Materials

g) Other

Subtotal

VRC Licensing Costs

Contingency $(25 \%)$

Total, Changes

(a) Spent Fuel Requirements, DOE/RL-84-1, May 1984.

(b) A indicates common pool shared by two reactors.

$B$ indicates pools connected by transfer canal.

$C$ indicates pools connected by cask transfer.

(c) The distance from the operating deck to the bottom of the crane hook at its uppermost position.

(d) Refers to the respective usable dimension (i.e., length, width, or depth) of the cask loading well. 
Plant Name: Oconee-1

Utility: Duke Power Company

Nearest Town: Seneca, SC

NRC Docket Number: 50-269

Reactor Type: PWR

Rating: (a) 886 MWe

In Plant Handling Parameters:

Share Pool: (b) No

Preferred Cask: Truck

Cask Experience: $\mathrm{NAC}-1$ and $\mathrm{NLI}-1 / 2$

Cask Crane Capacity, tons: 100

Crane height, ft: (c) 23.7

Pool Depth, ft: (d) 44.0

Pool Width, ft: (d) 7.1

Pool Length, ft: (d) 8.7

Comments: Can only handle smaller casks. In order to use an overweight cask the plant would need to be modified.

\section{ESTIMATED COSTS OF THIS PROJECT}

Estimated Costs, in Millions of

Cost Category 1984 Dollars

Changes:

Spur track:

a) 1 mile(s) track, onsite 0.32

b) 9 mile(s) track, offsite 6.18

c) $9 \mathrm{mile}(\mathrm{s})$ right-of-way offsite 0.09

d) Other--studies

$\underline{0.01}$

Subtotal

6.69

Cask Handling Crane:

e) Alter trolley (replacement) 0.8

f) Installation and Materials 0.2

g) Dther

Subtotal

NRC Licensing Costs

Contingency (25\%)

Tota 1 , Changes

$$
\begin{aligned}
& \frac{1.0}{0.11} \\
& 1.95 \\
& \hline 9.75
\end{aligned}
$$

(a) Spent Fuel Requirements, D0E/RL-84-1, May 1984.

(b) A indicates common pool shared by two reactors.

$B$ indicates pools connected by transfer canal.

$C$ indicates pools connected by cask transfer.

(c) The distance from the operating deck to the botton of the crane hook at its uppermost position.

(d) Refers to the respective usable dimension (i.e., length, width, or depth) of the cask loading well. 
Plant Name: Oconee-2

Utility: Duke Power Company

Nearest Town: Seneca, SC

NRC Docket Number: 50-270

Reactor Type: PWR

Rating: (a) 886 MWe

In Plant Handling Parameters:

Share Pool: (b) No

Preferred Cask: NAC-1, NLI-1/2

Cask Experience: $\mathrm{NAC}-1, \mathrm{NLI}-1 / 2$

Cask Crane Capacity, tons: 100

Crane height, ft: (c) 23.7

Pocl Depth, ft: (d) 44.0

Pool Width, ft: (d) 7.1

Pool Length, ft: (d) 8.7

Comments: See comments; Oconee-1

ESTIMATED COSTS OF THIS PROJECT

Comments: Oconee 1 and 2 share a common pool; therefore, onty the crane for linit 1 is altered and only a single spur track is assumed for purposes of this cost estimate.

(a) Spent Fuel Requirements, DDE/RL-84-1, May 1984.

(b) $\bar{A}$ indicates common poot shared by two reactors.

$B$ indicates pools connected hy transfer canal.

$C$ indicates pools connected by cask transfer.

(c) The distance from the operating deck to the hottom of the crane hook at its uppermost position.

(d) Refers to the respective usable dimension (i.e., length, width, or depth) of the cask loading well. 
Plant Name: Oconee-3

Utility: Duke Power Company

Nearest Town: Seneca, SC

NRC Docket Number: 50-287

Reactor Type: PWR

Rating: (a) 886 MWe

In Plant Handling Parameters:

Share Pool: (b) No

Preferred Cask: TN-8L

Cask Experience: NAC-1, NLI-1/2

Cask Crane Capacity, tons: 100

Crane height, ft: ${ }^{(c)} 23.8$

Pool Depth, ft: (d) 44

Pool Width, ft: (d) 7.2

Pool Length, ft: (d) 8.9

Comments: The licensee judges the TN-8L cask to be the largest spent fuel cask that could be handled at this plant.

\section{ESTIMATED COSTS OF THIS PROJECT}

Estimated Costs, in Millions of

Cost Category 1984 Dollars

Changes:

Spur track:

a) 1 mile(s) track, onsite

0.32

b) mile(s) track, offsite

c) mile(s) right-of-way offsite

d) other--study

0.01

Subtotal

0.33

Cask Handling Crane:

e) Alter trolley (replacement)

0.8

f) Installation and Materials

g) Other

Subtotal

1.0

NRC Licensing Costs

0.11

Contingency (25\%)

Total, Changes

0.36

$\overline{1.80}$

(a) Spent Fuel Requirements, DOE/RL-84-1, May 1984.

(b) A indicates common poo! shared by two reactors.

$B$ indicates pools connected by transfer canal.

$C$ indicates pools connected by cask transfer.

(c) The distance from the operating deck to the bottom of the crane hook at its uppermost position.

(d) Refers to the respective usable dimension (i.e., length, width, or depth) of the cask loading well. 
Plant Name: Oyster Creek

Utility: Jersey Central Power and Light Co.

Nearest Town: Forked River, NJ

NRC Docket Number: 50-219

Reactor Type: BWR

Rating: (a) 620 MWe

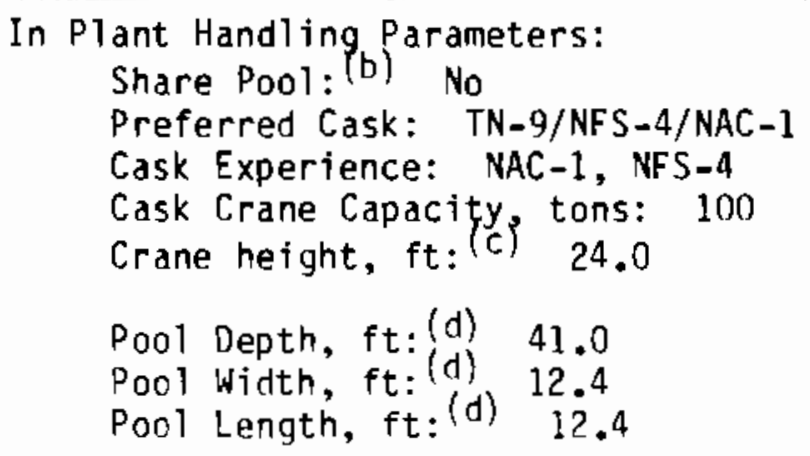

Comments: The spent fuel pool (SFP) has no cask "well." A $153 \mathrm{sq}$ ft area is set aside in the SFP for cask handling operations. The facility access doors must be closed during cask operations.

ESTIMATED COSTS OF THIS PROJECT

Estimated Costs,

Cost Category in Millions of 1984 Dollars

Changes:

Spur track:

a) 1 mile(s) track, onsite 0.32

b) 14 mile(s) track, offsite 9.61

c) $14 \mathrm{mile}(\mathrm{s})$ right-of-way offsite 0.14

d) $\overline{\text { Other--studies }}$

Subtotal

0.10

10.17

Cask Handling Crane:

e) Alter trolley (replacement) 0.8

f) Installation and Materials 0.2

g) Other

Subtotal

$\overline{1.0}$

NRC Licensing Costs

Cont ingency (25\%)

Total, Changes

0.11

$\frac{2.82}{14.10}$

(a) Spent Fuel Requirements, D0E/RL-84-1, May 1984.

(b) A indicates common pool shared by two reactors.

$B$ indicates pools connected by transfer canal.

$C$ indicates pools connected by cask transfer.

(c) The distance from the operating deck to the hottom of the crane hook at its uppermost position.

(d) Refers to the respective usable dimension (i.e., length, width, or depth) of the cask loading well. 
Plant Name: Palisades

Utility: Consumers Power Company

Nearest Town: South Haven, MI

NRC Docket Number: 50-255

Reactor Type: PWR

Rating: (a) 740 MWe

In Plant Handling Parameters:

Share Pool: (b) No

Preferred Cask: NAC-1

Cask Experience:

Cask Crane Capacity, tons: 100

Crane height, ft: $(c) 27.0$

Pool Depth, ft: (d) 40.6

Pool Width, ft: (d) 7.4

Pool Length, ft: (d) 7.4

Comments: Main spent fuel pool crane capacity derated from 100 to 25 tons as a result of heavy object drop analysis. It will take 1.5 years to upgrade crane. This is being deferred until need is shown.

\section{Changes:}

Spur track:

a) 1 mile(s) track, onsite 0.32

b) mile(s) track, offsite

c) mile(s) right-of-way offsite

d) Other--study

$\underline{0.01}$

Subtotal

0.33

Cask Handing Crane:

e) Alter trolley (replacement) 0.8

f) Installation and Materials 0.2

g) nther

Subtotal

1.0

NRC Licensing Costs $\quad 0.11$

Contingency (25\%) $\quad 0.36$

Total, Changes $\quad \overline{1.80}$

(a) Spent Fuel Requirements, D0E/RL-84-1, May 1984.

(b) A indicates common pool shared by two reactors. $B$ indicates pools connected by transfer canal.

$C$ indicates pools connected by cask transfer.

(c) The distance from the operating deck to the bottom of the crane hook at its uppermost position.

(d) Refers to the respective usable dimension (i.e., length, width, or depth) of the cask loading well. 
PTant Name: Peach Bottom-2

Utility: Philadelphia Electric Company

Nearest Town: Peach Bottom, PA

NRC Docket Number: 50-277

Reactor Type: BWR

Rating: (a) 1051 MWe

In Plant Handling Parameters:

Share Pool: (b) No

Preferred Cask: None Specified

Cask Experience: NL $1-1 / 2$

Cask Crane Capacity, tons: 125

Crane height, ft: (c) 32.0

Pool Depth, ft: (d) 39.0

Pool Width, ft: (d) 9.0

Pool Length, ft: (d) 9.0

Comments: A car puller is used to move cask trailers in the fuel handling facility.

Estimated Costs, in Millions of

Cost Category

1984 Dollars

Shanges:

Spur track: (repair)

a) 1 mile(s) track, onsite 0.32

b) 19 mile(s) track, offsite 13.04

c) mile(s) right-of-way offsite

d) Jther--study

$\underline{0.01}$

Subtotal

13.37

i.ask Handling Crane:

e) Alter trolley (replacement)

f) Installation and Materials

g) Other

Subtotal

NRC Licensing Costs

Cont ingency (25\%)

Total, Changes

$\frac{3.34}{16.71}$

(a) Spent Fuel Requirements, DOE/RL-84-1, May 1984.

(b) A indicates common poot shared by two reactors.

$B$ indicates pools connected hy transfer canal.

$C$ indicates pools connected by cask transfer.

(c) The distance from the operating deck to the bottom of the crane hook at its uppermost position.

(d) Refers to the respective usable dimension (i.e., length, width, or depth) of the cask loading well. 
Plant Name: Peach Bottom-3

Utility: Philadelphia Electric Company

Nearest Town: Peach Bottom, PA

NRC Docket Number: 50-278

Reactor Type: BWR

Rating: (a) 1035 MWe

In Plant Handling Parameters:

Share Pool: (b) No

Preferred Cask: None Specified

Cask Experience: NLI-1/2

Cask Crane Capacity, tons: 125

Crane height, $\mathrm{ft}:{ }^{(\mathrm{c})} 32.0$

Pool Deptb, ft: (d) 39.0

Pool Width, ft: (d) 9.0

Pool Length, ft: (d) 9.0

Comments: See comments; Peach Bottom-2.

\section{ESTIMATED COSTS OF THIS PROJECT}

Cost Category

Estimated Costs, in Millions of 1984 Dollars

Changes:

Spur track: (repair)

a) 1 mile(s) track, onsite

0.32

b) mile(s) track, offsite

c) mile(s) right-of-way offsite

d) Other--study

0.01

Subtotal

0.33

Cask Handling Crane:

e) Alter trolley (replacement)

f) Installation and Materials

g) Other

Subtotal

NRC Licensing Costs

Cont ingency (25\%)

Total, Changes

$\frac{0.08}{0.41}$

(a) Spent Fuel Requirements, n0E/RL-84-1, May 1984.

(b) A indicates common pool shared by two reactors.

$B$ indicates pools connected by transfer canal.

$C$ indicates pools connected by cask transfer.

(c) The distance from the operating deck to the bottom of the crane hook at its uppermost position.

(d) Refers to the respective usable dimension (i.e., length, width, or depth) of the cask loading well. 
Plant Name: Pilgrim-1

Utility: Boston Edison Company

Nearest Town: Plymouth, MA

NRC Docket Number: 50-293

Reactor Type: BWR

Rating: (a) 670 MWe

In Plant Handling Parameters:

Share Pool: (b) No

Preferred Cask: None Specified

Cask Experience:

Cask Crane Capacity, tons: 100

Crane height, ft: (c) 23

Pool Depth, ft: (d) 39.0

Pool Width, ft: (d) 7.0

Pool Length, ft: (d) 10.0

Comments: None.

Cost Category

Est imated Costs, in Millions of

1984 Dollars

Changes:

Spur track:

a) 1 mile(s) track, onsite

0.32

b) 9 mile(s) track, offsite

6.18

c) $9 \mathrm{mile}(\mathrm{s})$ right-of-way offsite

0.09

d) other--studies

$\underline{0.10}$

Subtotal

6.69

Cask Handling Crane:

e) Alter trolley (replacement) 0.8

f) Installation and Materials 0.2

g) Other

Subtotal

1.0

NRC Licensing Costs 0.11

Contingency (25\%) $\quad 1.95$

Total, Changes $\quad \overline{9.75}$

(a) Spent Fuel Requirements, DOE/RL-84-1, May 1984.

(b) A indicates common pool shared by two reactors.

$B$ indicates pools connected by transfer canal.

$C$ indicates pools connected by cask transfer.

(c) The distance from the operating deck to the bottom of the crane hook at its uppermost position.

(d) Refers to the respective usable dimension (i.e., length, width, or depth) of the cask loading well. 
Plant Name: Salem-1

Utility: Public Service Electric and Gas Co.

Nearest Town: Salem, NJ

NRC Docket Number: $50-272$

Reactor Type: PWR

Rating: (a) 1079 MWe

In Plant Handling Parameters:

Share Pool: (b) No

Preferred Cask: NAC-1, NLI $1 / 2$

Cask Experience:

Cask Crane Capacity, tons: 110

Crane height, ft: $(c) \quad 30.5$

Pool Depth, ft: (d) 45.D

Pool Width, ft: (d) 12.0

Pool Length, ft: (d) 12.0

Comments: Small cover $\left(9^{\prime} \times 9^{\prime}\right)$ on decontamination pit but this could be enlarged to $19.5^{\prime} \times 20^{\prime}$ by removal of a checkerboard plate. Receiving hatch is $30^{\prime} \times 10^{\prime}$.

ESTIMATED COSTS OF THIS PROJECT

Cost Category

Estimated Costs, in Millions of

Changes:

1984 Dollars

Spur track:

a) $1 \mathrm{mile}(\mathrm{s})$ track, onsite 0.32

b) $14 \mathrm{mile}(\mathrm{s})$ track, offsite 9.61

c) 14 mile(s) right-of-way offsite 0.14

d) other--studies

Subtotal

10.17

Cask Handling Crane:

e) Alter trolley (replacement)

f) Installation and Materials

g) Other

Subtotal

NRC Licensing Costs

Contingency (25\%)

Total, Changes

(a) Spent Fuel Requirements, D0E/RL-84-1, May 1984.

(b) A indicates common pool shared by two reactors.

$B$ indicates pools connected by transfer canal.

$C$ indicates pools connected by cask transfer.

(c) The distance from the operating deck to the bottom of the crane hook at its uppermost position.

(d) Refers to the respective usable dimension (i.e., length, width, or depth) of the cask loading well. 
Plant Name: Salem-2

Utility: Public Service Electric and Gas Co.

Nearest Town: Salem, NJ

NRC Docket Number: 50-311

Reactor Type: PWR

Rating: (a) 1106 MWe

In Plant Handling Parameters:

Share Pool: (b) No

Preferred Cask: NAC-1, NLI $1 / 2$

Cask Experience:

Cask Crane Capacity, tons: 110

Crane height, ft: (c) 30.5

Pool Depth, ft: (d) 45.0

Pool Width, ft: (d) 12.0

Pool Length, ft: ${ }^{(d)} 12.0$

Comments: See comments; Salem-1.

ESTIMATED COSTS OF THIS PROJECT

Cost Category

Estimated Costs, in Millions of

1984 Dollars

Changes:

Spur track:

a) $1 \mathrm{mile}(\mathrm{s})$ track, onsite 0.32

b) mile(s) track, offsite

c) mile(s) right-of-way offsite

d) Tther--study

0.01

Subtotal

0.33

Cask Handling Crane:

e) Alter trolley (replacement)

f) Installation and Materiais

g) Other

Subtotal

NRC Licensing Costs

Contingency (25\%)

Tota T, Changes

$\frac{0.08}{0.41}$

(a) Spent Fuel Requirements, D0E/RL-84-1, May 1984.

(b) $\bar{A}$ indicates common pool shared by two reactors.

$B$ indicates pools connected by transfer canal.

$C$ indicates pools connected by cask transfer.

(c) The distance from the operating deck to the bottom of the crane hook at its uppermost position.

(d) Refers to the respective usable dimension (i.e., length, width, or depth) of the cask loading well. 
Plant Name: San Onofre-1

Utility: Southern California Edison Company

Nearest Town: San Clemente, CA

NRC Docket Number: 50-206

Reactor Type: PWR

Rating: (a) 387 MWe

In Plant Handling Parameters:

Share Pool: (b) C

Preferred Cask: IF-300, NAC-1

Cask Experience: $\mathrm{NAC}-1$

Cask Crane Capacity, tons: 100

Crane height, ft: (C) 65.0

Pool Depth, ft: (d) 40.0

Pool Width, ft: (d) 11.0

Pool Length, ft: (d) 11.0

Comments: Did some partial shipments from Unit 1 in 1981.

\section{ESTIMATED CDSTS OF THIS PROJECT}

Estimated Costs, in Millions of

Cost Category 1984 Dollars

Changes:

Spur track:

a) <1 mile(s) track, onsite 0.32

b) mile(s) track, offsite

c) mile(s) right-of-way offsite

d) Dther--study

Subtotal

0.01

0.33

Cask Handling Crane:

e) Alter trolley (replacement) 0.8

f) Installation and Materials 0.2

g) Other

Subtotal

1.0

NRC Licensing Costs 0.11

Contingency (25\%) $\quad 0.36$

Total, Changes $\quad \mathbf{1 . 8 0}$

(a) Spent Fuel Requirements, DOE/RL-84-1, May 1984.

(b) A indicates comon pool shared by two reactors.

$B$ indicates pools connected by transfer canal.

$C$ indicates pools connected by cask transfer.

(c) The distance from the operating deck to the bottom of the crane hook at its uppermost position.

(d) Refers to the respective usable dimension (i.e., length, width, or depth) of the cask loading well. 
Plant Name: San Onofre-2

Utility: Southern California Edison Company

Nearest Town: San Clemente, CA

NRC Docket Number: 50-361

Reactor Type: PWR

Rating: (a) 1100 MWe

In Plant Handling Parameters:

Share Pool: (b) C

Preferred Cask: Unknown

Cask Experience:

Cask Crane Capacity, tons: 125

Crane height, ft: (c) 32.D

Pool Depth, ft: (d) 47.0

Pool Width, ft: (d) 21.0

Pool Length, ft: (d) 23.0

Comments: See comments; San Onofre-1.

ESTIMATED COSTS OF THIS PROJECT

Estimated Costs, in Millions of

Cost Category 1984 Dollars

Changes:

Spur track:

a) <l mile(s) track, onsite 0.32

b) mile(s) track, offsite

c) - mile(s) right-of-way offsite

d) other--study

0.01

Subtotal

0.33

Cask Handling Crane:

e) Alter trolley (replacement)

f) Installation and Materials

g) Other

Suhtotal

NRC Licensing Costs

Cont ingency (25\%)

Total, Changes

0.08

$\overline{0.41}$

(a) Spent Fuel Requirements, DOE/RL-84-1, May 1984.

(b) A indicates common pool shared by two reactors. $B$ indicates pools connected by transfer canal.

$C$ indicates pools connected by cask transfer.

(c) The distance from the operating deck to the bottom of the crane hook at its uppermost position.

(d) Refers to the respective usable dimension (i.e., length, width, or depth) of the cask loading well. 
Plant Name: San Onofre-3

Utility: Southern California Edison Co.

Nearest Town: San Clemente, CA

NRC Docket Number: 50-362

Reactor Type: PWR

Rating: (a) 1100 MWe

In Plant Handling Parameters:

Share Pool: $(b) \quad C$

Preferred Cask:

Cask Experience:

Cask Crane Capacity, tons: 125

Crane height, $\mathrm{ft}:(\mathrm{c}) \quad 32.0$

Pool Depth, ft: (d) 47.0

Pool Width, ft: (d) 21.0

Pool Length, ft: (d) 23.0

Comments: See comments; San Onofre-1.

ESTIMATED COSTS OF THIS PROJECT

Estimated Costs, in Millions of

Cost Category 1984 Dollars

Changes:

Spur track:

a) $<1$ mile(s) track, onsite 0.32

b) mile(s) track, offsite

c) mile(s) right-of-way offsite

d) Other--study

$\underline{0.01}$

Subtotal

0.33

Cask Handling Crane:

e) Alter trolley (replacement)

f) Installation and Materials

g) Other

Subtotal

NRC Licensing Costs

Contingency $(25 \%)$

Total, Changes

$\frac{0.08}{0.41}$

(a) Spent Fuel Requirements, DoE/RL-84-1, May 1984.

(b) A indicates common poot shared by two reactors.

$B$ indicates pools connected by transfer canal.

$C$ indicates pools connected by cask transfer.

(c) The distance from the operating deck to the bottom of the crane hook at its uppermost position.

(d) Refers to the respective usable dimension (i.e., length, width, or depth) of the cask loading well. 
Plant Name: Shoreham

Utility: Long Island Lighting Company

Nearest Town: Brookhaven, NY

NRC Docket Number: $50-322$

Reactor Type: BWR

Rating: (a) 819 MWe

In Plant Handling Parameters:

Share Pool: (b) No

Preferred Cask: Truck

Cask Experience: No

Cask Crane Capacity, tons: 125

Crane height, ft: (c) 26.3

Pool Depth, ft: (d) 38.8

Pool Width, ft: (d)

Pool Length, ft: (d)

Comments: Cask pool is a 73 sq $\mathrm{ft}$. quadrant of the spent fuel pool. Have had a trailer truck in building where loading would occur.

\section{ESTIMATED COSTS OF THIS PROJECT}

Estimated Costs,

\section{Cost Category} in Millions of 1984 Dollars

Changes:

Spur track:

a) 1 mile(s) track, onsite

0.32

b) 9 mile(s) track, offsite

6.18

c) 9 mile(s) right-of-way of fsite

0.09

d) other--studies

0.01

Subtota1

6.69

Cask Handing Crane:

e) Alter trolley (replacement)

f) Installation and Materials

g) Other

Subtotal

NRC Licensing Costs

Contingency (25\%)

Total, Changes

(a) Spent Fuel Requirements, D0E/RL-84-1, May 1984.

(b) $\bar{A}$ indicates common poot shared by two reactors.

$B$ indicates pools connected by transfer canal.

$C$ indicates pools connected by cask transfer.

(c) The distance from the operating deck to the bottom of the crane hook at its uppermost position.

(d) Refers to the respective usable dimension (i.e., length, width, or depth) of the cask loading well. 
Plant Name: Surry-1

Utility: Virginia Electric Power Company

Nearest Town: Gravel Neck, VA

NRC Docket Number: $50-280$

Reactor Type: PWR

Rating: (a) 775 MWe

In Plant Handling Parameters:

Share Pool: (b) A

Preferred Cask: TN-8L

Cask Experience: TN-8L

Cask Crane Capacity, tons: 125

Crane height, ft: (c) 29.0

Pool Depth, ft: (d) 40.5

Pool Width, ft: (d) 12.0

Pool Length, ft: (d) 12.0

Comments: Units 1 and 2 have single access doors which must be closed during cask operations. May be shipping with TN-9 in near future.

\section{ESTIMATED COSTS OF THIS PRO.JECT}

Estimated Costs,

Cost Category

Changes:

Spur track:

a) $1 \mathrm{mile}(\mathrm{s})$ track, onsite

0.32

b) $25 \mathrm{mile}(\mathrm{s})$ track, offsite

17.16

c) 25 mile(s) right-of-way offsite

0.25

d) Other-ostudies

$\underline{0.10}$

Subtotal

17.83

Cask Handling Crane:

e) Alter trolley (replacement)

f) Installation and Materials

g) Other

Subtotal

NRC Licensing Costs

Contingency (25\%)

Total, Changes

(a) Spent Fuel Requirements, D0E/RL-84-1, May 1984.

(b) A indicates common pool shared by two reactors.

$B$ indicates pools connected hy transfer canal.

$C$ indicates pools connected by cask transfer.

(c) The distance from the operating deck to the bottom of the crane hook at its uppermost position.

(d) Refers to the respective usable dimension (i.e., length, width, or depth) of the cask Toading well. 
Plant Name: Surry-2

Utility: Virginia Electric Power Company

Nearest Town: Gravel Neck, VA

NRC Docket Number: 50-281

Reactor Type: PWR

Rating: (a) 775 MWe

In Plant Handling Parameters:

Share Pool: (b) A

Preferred Cask: TN-8L

Cask Experience: TN-8L

Cask Crane Capacity, tons: 125

Crane height, ft: (C) 29.0

Pool Depth, ft: (d) 40.5

Pool Width, ft: (d) 12.0

Pool Length, ft: (d) 12.0

Comments: See comments; Surry-1.

\section{ESTIMATED COSTS OF THIS PROJECT}

Comments: Surry 1 and 2 share a common pool; therefore, only a single spur track is assumed for purposes of this cost estimate.

(a) Spent Fuel Requirements, DOE/RL-84-1, May 1984.

(b) A indicates common pool shared by two reactors.

$B$ indicates pools connected by transfer canal.

$C$ indicates pools connected by cask transfer.

(c) The distance from the operating deck to the bottom of the crane hook at its uppermost position.

(d) Refers to the respective usable dimension (i.e., length, width, or depth) of the cask loading well. 
Plant Name: Trojan

Utility: Portland General Electric Company

Nearest Town: Prescott, OR

NRC Docket Number: 50-344

Reactor Type: PWR

Rating: (a) 1080 MWe

In Plant Handling Parameters:

Share Pool: (b) No

Preferred Cask:

Cask Experience:

Cask Crane Capacity tons: 125

Crane height, ft: $(\mathrm{c}) \quad 30.0$

Pool Depth, ft: (d) 43.5

Pool Width, ft: (d) 9.0

Pool Length, ft: (d) 12.0

Comments: None.

\section{ESTIMATED COSTS OF THIS PROJECT}

Estimated Costs, in Millions of

Cost Category 1984 Dollars

Changes:

Spur track:

a) $<1 \mathrm{mile}(\mathrm{s})$ track, onsite 0.32

b) mile(s) track, offsite

c) mile(s) right-of-way offsite

d) other--study

$\underline{0.01}$

Subtotal

0.33

Cask Handling Crane:

e) Alter trolley (replacement)

f) Installation and Materials

g) Other

Subtotal

NRC Licensing Costs

Contingency (25\%)

Total, Changes

(a) Spent Fuel Requirements, D0E/RL-84-1, May 1984.

(b) A indicates common pool shared by two reactors.

$B$ indicates pools connected by transfer canal.

$C$ indicates pools connected by cask transfer.

(c) The distance from the operating deck to the bottom of the crane hook at its uppermost position.

(d) Refers to the respective usable dimension (i.e., length, width, or depth) of the cask loading well. 
Plant Name: Turkey Point -3

Utility: Florida Power and Light Co.

Nearest Town: Florida City, FL

NRC Docket Number: $50-250$

Reactor Type: PWR

Rating: (a) 646 MWe

In Plant Handling Parameters:

Share Pool: (b) No

Preferred Cask: LWT

Cass Experience: NAC-1, NFS-4, NLI $1 / 2$

Cask Crane Capacity, tons: 105

Crane height, ft: ${ }^{(C)} 9.4$

Pool Depth, ft: (d) 40.0

Pool Width, ft: (d) 9.8

Pool Length, ft: (d) 10.1

Comments: Turkey Point units are limited by license to the use of single assembly casks with a 25-ton cask weight limit.

\section{ESTIMATED COSTS OF THIS PROJECT}

Estimated Costs, in Millions of

Cost Category 1984 Dollars

Lhanges:

Spur track:

a) 1 mile(s) track, onsite 0.32

b) $9 \mathrm{mile}(\mathrm{s})$ track, offsite 6.18

c) 9 mile(s) right-of-way offsite 0.09

d) Dther-studies

$\underline{0.01}$

Subtotal

6.69

liask Handling Crane:

e) Alter trolley (replacement) 0.8

f) Installation and Materials 0.2

g) Other

Subtotal

1.0

NRC Licensing Costs 0.11

Contingency (25\%) $\quad 1.95$

Tota1, Changes $\quad \overline{9.75}$

(a) Spent Fuel Requirements, 00E/RL-84-1, May 1984.

(b) A indicates common poot shared by two reactors.

$B$ indicates pools connected by transfer canal.

$C$ indicates pools connected by cask transfer.

(c) The distance from the operating deck to the bottom of the crane hook at its uppermost position.

(d) Refers to the respective usable dimension (i.e., length, width, or depth) of the cask loading well. 
Plant Name: Turkey Point -4

Utility: Florida Power and Light Co.

Nearest Town: Florida City, FL

NRC Docket Number: 50-251

Reactor Type: PWR

Rating: (a) 646 MWe

In Plant Handling Parameters:

Share Pool: (b) No

Preferred Cask: LWT

Cask Experience: NAC-1, NFS-4, NLI $1 / 2$

Cask Crane Capacity, tons: 105

Crane height, ft: (c) 9.4

Pool Depth, ft: (d) 40.0

Pool Width, ft: (d) 9.8

Pool Length, ft: (d) 10.1

Comments: See comments; Turkey Point-3.

ESTIMATED COSTS OF THIS PROJECT

Estimated Costs, in Millions of

Cost Category 1984 Dollars

Changes:

Spur track:

a) $<1 \mathrm{mile}(\mathrm{s})$ track, onsite 0.32

b) mile(s) track, offsite

c) mile(s) right-of-way offsite

d) Jther--study

0.01

Subtotal

0.33

Cask Handling Crane:

e) Alter trolley (replacement)

0.8

f) Installation and Materials

0.2

g) Other

Subtotai

1.0

NRC Licensing Costs

0.11

Contingency (25\%)

Total, Changes

$\frac{0.36}{1.80}$

(a) Spent Fuel Requirements, D0E/RL-84-1, May 1984.

(b) A indicates common poot shared by two reactors.

$B$ indicates pools connected by transfer canal.

$C$ indicates pools connected by cask transfer.

(c) The distance from the operating deck to the bottom of the crane hook at its uppermost position.

(d) Refers to the respective usable dimension (i.e., length, width, or depth) of the cask loading well. 
Plant Name: WNP-2

Utility: Washington Public Power Supply System

Nearest Town: Richland, WA

NRC Docket Number: 50-397

Reactor Type: BWR

Rating: (a) 1100 MWe

In Plant Handling Parameters:

Share Pool: (b) No

Preferred Cask: None

Cask Experience: No

Cask Crane Capacity, tons: 125

Crane height, ft: (c) 28.9

Pool Depth, ft: (d) 39.0

Pool Width, ft: (d) 8.0

Pool Length, ft: (d) 8.0

Comments: Cask well is an 8 ' outside diameter shaft in the southeast corner of the spent fuel pool.

ESTIMATED COSTS OF THIS PROJECT

Estimated Costs, in Millions of

Cost Category 1984 Dollars

Changes:

Spur track:

a) $<0.5 \mathrm{mile}(\mathrm{s})$ track, onsite

0.16

b) mile(s) track, offsite

c) mile(s) right-of-way offsite

d) $\overline{\text { ther--study }}$

0.01

Subtotal

0.17

Sask Handling Crane:

e) Alter trolley (replacement)

f) Installation and Materials

g) Other

Subtotal

VRC Licensing Costs

Contingency $(25 \%)$

Tota1, Changes

$\frac{0.04}{0.21}$

(a) Spent Fue1 Requirements, D0E/RL-84-1, May 1984.

(b) $A$ indicates common pool shared by two reactors.

$B$ indicates pools connected by transfer canal.

$C$ indicates pools connected by cask transfer.

(c) The distance from the operating deck to the bottom of the crane hook at its uppermost position.

(d) Refers to the respective usable dimension (i.e., length, width, or depth) of the cask loading well. 

. 


\section{DISTRIBUTION}

No. of

Copies

OFFSITE

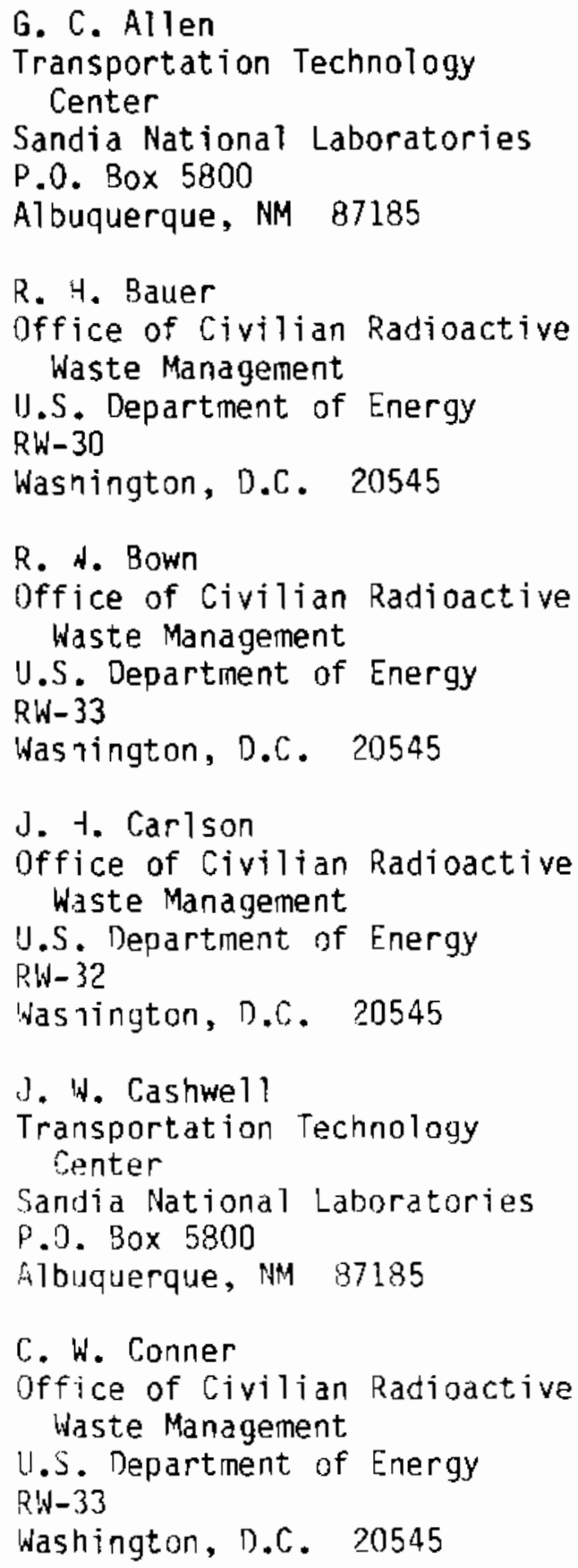

G. C. Allen

Transportation Technology Center

Sandia National Laboratories

P.0. Box 5800

Albuquerque, NM 87185

R. 4. Bauer

Office of Civilian Radioactive Waste Management

IJ.S. Department of Energy

RH-30

Wasnington, D.C. 20545

R. H. Bown

Office of Civilian Radioactive Waste Management

U.S. Department of Energy

RW- 33

Was nington, D.C. 20545

J. t. Carlson

Office of Civilian Radioactive Waste Management

U.S. Department of Energy

RW- 32

Was vington, D.C. 20545

J. W. Cashwell

Transportation Technology Center

Sandia National Laboratories

P.0. Box 5800

Albuquerque, NM 87185

C. W. Conner

Office of Civilian Radioactive Waste Management

U.S. Department of Energy

$\mathrm{R} W \mathrm{~N}-33$

Washington, D.C. 20545

No. of

Copies

\author{
S. H. Denny \\ Office of Civilian Radioactive \\ Waste Management \\ U.S. Department of Energy \\ RW-33 \\ Washington, D.C. 20545 \\ J. R. Hilley \\ Office of Civilian Radioactive \\ Waste Management \\ U.S. Department of Energy \\ RW-30 \\ Washington, D.C. 20545 \\ E. R. Johnson Associates, Inc. \\ 11702 Bowman Green Drive \\ Renton, VA 22090 \\ K. A. Klein \\ Office of Civilian Radioactive \\ Waste Management \\ U.S. Department of Energy \\ RW-31 \\ Washington, D.C. 20545 \\ R. W. Lambert \\ Electric Power Research \\ Inst itute \\ P.0. Rox 10412 \\ Palo Aito, CA 94304 \\ W. J. Lee \\ Nuclear Assurance Corp. \\ 5720 Peachtree Parkway \\ Norcross, GA 10601 \\ R. E. Luna \\ Transportation Technology \\ Center \\ Sandia National Laboratories \\ P.0. Box 5800 \\ Albuquerque, NM 87185
}


No. of

Copies

T. G. Nguyen

Office of Civilian Radioactive Waste Management

U.S. Department of Energy

RW-33

Washington, D.C. 20545

R. E. Philpott

Office of Civilian Radioactive Waste Management

U.S. Department of Energy

RW-33

Washington, D.C. 20545

0 . E. Shelor

Office of Civilian Radioactive Waste Management

U.S. Department of Energy

$\mathrm{RW}-32$

Washington, D.C. 20545

B. R. Teer

Transnuclear, Inc.

One North Broadway

White PTains, NY 10601

R. F. Williams

Electric Power Research Institute

P.0. Box 10412

Palo Alto, CA 94304

E. L. Wilmot

Office of Civilian Radioactive Waste Management

U.S. Department of Energy

RW-33

Washington, D.C. 20545

DOE Technical Information Center
No. of

Copies

ONSITE

4 DOE Richland Operations Office

D. E. Crouter

J. L. Oaily

D. C. Langstaff

D. Segna

1 Hanford Engineering Development Laboratory

J. D. Berger

58 Pacific Northwest Laboratory

W. W. Ballard

G. H. Beeman

B. M. Cole

C. A. Counts

J. W. Curry

P. M. Daling

J. F. Fletcher

R. J. Ha il

G. M. Holter

G. J. Konzek (20)

D. S. Jackson

R. A. Libby

P. N. McOuffie

J. L. MCElroy

1. F. Nesbitt

D. F. Newman

D. R. Oden

K. J. Schneider

M. R. Shay

M. R. Triplett (10)

R. C. Walling

M. K. White

T. W. Wood

Publishing Coordination MH (2)

Technical Information (5) 